\title{
Work-based identity and work engagement as potential antecedents of task performance and turnover intention: Unravelling a complex relationship
}

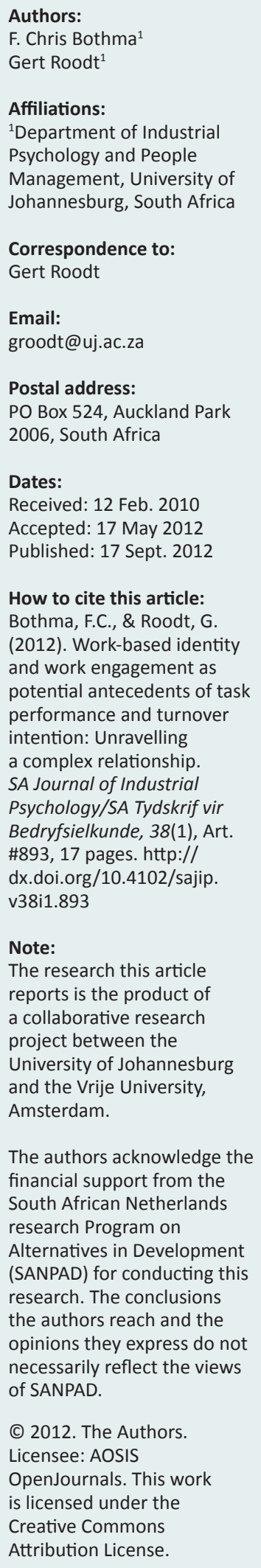

F. Chris Bothma

Gert Roodt

Management, University of

Correspondence to:

Email:

O Box 524, Auckland Park

Accepted: 17 May 2012

Published: 17 Sept. 2012

cite this article:

Bothma, F.C., \& Roodt, G.

. Work-based identity

potential antecedents of tas

intention: Unravelling

Psychology/SA Tydskrif vir

(B)

dx.doi.org/10.4102/sajip.

v38i1.893

reports is the product of

a collaborative research

project between the

Amsterdam.

The authors acknowledge th financial support from the South African Netherlands research Program on in Development the authors reach and the opinions they express do not necessarily reflect the views

is licensed under the

Attribution License.
Orientation: Work-based identity, used as a reference to the self, is the answer to the question 'Who am I at work?' Work-related identities, derived from different social foci through identity formation processes, have as behavioural guides a significant influence on employee behaviour, which, in turn has an impact on work outcomes. Engagement, presented in different conceptualisations, is viewed by practitioners and academic researchers as an important antecedent of employee behaviour.

Research purpose: The main purpose of the study was to investigate whether work-based identity and work engagement differed (in combination with personal alienation, helping behaviour and burnout) as potential antecedents (amongst numerous others) of task performance and turnover intention.

Research design: A census-based sampling approach amongst 23134 employees in the employment of an ICT company yielded a sample of 2429 usable questionnaires. Scales used in the study were the Maslach Burnout Inventory (MBI-HSS-20), Utrecht Work Engagement Scale (UWES), Work-based Identity, Personal Alienation, Helping Behaviour, Turnover Intention and Task Performance Scales.

Main findings: The findings indicate that work-based identity and work engagement give similar appearing results as potential predictors of turnover intention and task performance.

Practical/managerial implications: Reducing withdrawal behaviours and enhancing work performance are everyday challenges for organisations. Interventions focused on enhancing work-based identity and work engagement in the work environment should have a meaningful impact when these behaviours need to be addressed.

Contribution/value-add: Work-based identity as a multidimensional construct has the potential, with further refinement, to become a valuable construct that can play a leading role in future work engagement research.

\section{Introduction}

Organisations strive for ways to improve employees' job performance and to retain their top performers (Ulrich, 1997). This necessitates a valid understanding of the determinants of job performance and turnover. Work-based identity and engagement have been offered as two potentially influential determinants (amongst numerous others) of task performance and turnover. Engagement, presented in different conceptualisations, is viewed by practitioners and academic researchers as an important antecedent of employee behaviour (Bakker \& Schaufeli, 2008; Harter, Schmidt \& Keyes, 2003; Macey \& Schneider, 2008; Schaufeli, Salanova, ConźalezRomá \& Bakker, 2002; Simpson, 2009). Another group of researchers see work-based identity as an important construct to understand and influence work-related behaviours (Agostino, 2004; Aryee \& Luk, 1996; Ashforth \& Kreiner, 1999; Buche, 2003, 2006, 2008; Pratt, Rockmann \& Kaufmann, 2006; Reijn, 2007; Walsh \& Gordon, 2007).

Substantial research literature is available on work-related identity and work engagement antecedents, construction, transformation and maintenance, but research focused on the impact of these constructs on organisational outcomes is sparse (Agostino, 2004; Bakker \& Schaufeli, 2008; Buche, 2003, 2006, 2008; Pratt et al., 2006; Macey \& Schneider, 2008; Schaufeli \& Bakker, 2001, 2003, 2004; Schaufeli, Bakker \& Salanova, 2006; Schaufeli et al., 2002; Walsh \& Gordon, 2007). In the available research it appears that work engagement shares two sub-concepts with work-based identity namely commitment (referring to the strength of an identity) and involvement (Macey \& Schneider, 2008; Schaufeli et al., 2002; Stets \& Burke, 2003). Job performance and turnover are two organisational outcomes (amongst numerous others) of work related processes. 
The research question can therefore be formulated as: 'What is the difference between the constructs work-based identity and work engagement?' The constructs work-based identity and work engagement are based on the different conceptual perspectives and theoretical foundations (as will be explained below), but also on a consideration of some of the shared content (as explained above). Consequently, the first objective of the study is to determine the relationships between work-based identity, work engagement, personal alienation, helping behaviour, and the burnout dimensions emotional exhaustion, depersonalisation and reduced personal accomplishment. The second objective is to determine if there is any difference between work-based identity and work engagement by testing their ability to predict turnover intention and task performance.

An understanding of the impact of work-related identities and work engagement can be useful when interventions that can positively influence work performance and outcomes which will, in turn, provide organisations with a competitive advantage are developed (Walsh \& Gordon, 2007). An example of this kind of intervention is to use work-based identity profiles in the identification, acquisition, and retention of key employees to ensure a sustainable competitive advantage over competitors (Buche, 2008). Another possible strategy to consider is interventions to influence or enhance work-based identity and work engagement construction and maintenance processes for the advancement of the organisation (Pratt et al., 2006; Reijn, 2007).

This article consists of four parts. Firstly a brief overview of the literature is provided to describe the related concepts and theories that form the building blocks or foundation for understanding the key concepts, work-based identity and work engagement. Secondly the research design is presented, and this is followed, thirdly, by the findings of the study. Lastly the article concludes with a discussion of the results.

\section{Review of the literature}

Identity is a key construct in social and behaviour research (Hogg, Terry \& White, 1995) and one of many terms that describe organisational behaviour (Albert, Ashforth \& Dutton, 2000). The term identity can be used in different contexts. In one context, the term refers to the existence of something that displays one or more attributes (characteristics). For example, organisation identity is a reference to all the attributes an organisation may possess; these attributes can include the values, goals, actions or descriptions of the organisation or its members (Lane \& Scott, 2007).

In another context, the term identity refers to the most basic understanding individuals have about themselves. According to Ravishankar and Pan (2008), this understanding can be described in accordance with two broad psychological dimensions: It is firstly, in absolute terms and with reference to the uniqueness of a personal or individual identity, the answer to the question, 'Who am I?' (Kirpal, 2004b).
In relation to other social categories or classifications that constitutes social identity, it is also the answer to the question, 'Who are we?' This is a reference to the individual's identification with a specific social group and to his conduct as part of that group (Korte, 2007).

Social identity provides a link between the social group (structures and processes) and the psychology of the individual (which refers to the self and the behaviour of the individual) (Brewer, 2001; Hogg et al., 1995). This construct evolved across all the social and behavioural science disciplines in an array of manifestations. Brewer (2001), for instance, grouped these social identity conceptualisations into person-based, relational, group-based and collective social identities.

Social identity theory and identity theory are two perspectives of the socially constructed self-concept, a product of individual behaviour and social structure (Hogg et al., 1995) that have developed parallel to each other in the different disciplinary branches of sociology and psychology. As theories of the self, they are remarkably similar, both explaining '...the dynamic mediation of the socially constructed self between individual behaviour and social structure' (Hogg et al., 1995, p. 255). Identity theory aims to describe individual role-related behaviours (roles), whilst social identity theory focuses on the categories of the collective self and on group and inter-group processes (Hogg \& Ridgeway, 2003; Hogg et al., 1995; Stets \& Burke, 2000).

Social identity theory conceptualised the self-concept as consisting of a personal identity (biographical uniqueness of the individual) and a unique set of social identities (attributes taken from different social focuses) (Ashforth \& Humphrey, 1993; Brewer \& Pierce, 2005). A person has a social identity if he or she sees himself or herself as belonging to a specific social group or category. According to the social identity theory, a social identity is formed through the processes of self-categorisation and social comparison (Hogg et al., 1995; Stets \& Burke, 2000).

Identity theory conceptualised the self as a multi-faceted social construct that emerges from the social roles people play (Hogg et al., 1995). The core of an identity is found where the self is regarded as an occupant of a role to which meanings and expectations (that guide behaviour) are attached. In identity theory an identity is formed through a process of identification (Hogg et al., 1995; Stets \& Burke, 2000). Having an identity enhances a person's sense of belonging somewhere (Agostino, 2004; Ashforth \& Mael, 1989; Hogg \& Terry, 2000; Kirpal, 2004a, 2004b). The two theories were compared and discussed in detail by Hogg and Ridgeway (2003), Hogg and Terry (2000), Hogg et al. (1995), Stets and Burke (2000) and Stryker and Serpe (1982).

The term identification needs clarification as different meanings can be attributed to the term. The term is used by researchers to describe both a cognitive state (Rousseau, 1998) and a process (Steers \& Porter, 1991). As a cognitive state, 
the term identification means that part of a person's social identity that is derived from a social group such as found in an occupation or organisation (Kreiner, Hollensbe \& Sheep, 2006). Kreiner et al. (2006) suggested that the term identity is more appropriate for describing the cognitive state. As a process, the term identification means the acceptance of '....influence in order to engage in a satisfying role-relationship with another person or group' (Steers \& Porter, 1991, p. 214). This means the alignment of the individuals self with that of the social group identity. When the individual identifies with and behaves as part of the specific social group, a social identity has been developed by the individual (Kreiner et al., 2006). Performing any job (playing a role) generates a certain level of identification with that job (Stets \& Burke, 2000; Kirpal, 2004a). The process that leads to the perception of oneness with the job (role) is referred to as identification (Ashforth \& Mael, 1989) and the outcome, according to identity theory, is a role identity (Stets \& Burke, 2000, Kirpal, 2004a).

Varying levels (degrees) of identification with specific social foci exist between individuals, and may range from low to high (Abdelal, Herrera, Johnston \& Martin, 2001; Coster, Norman, Murrells, Kitchen, Meerabeau, Sooboodoo \& d'Avray, 2008; Ibarra, 1999; Rousseau, 1998; Van Dick, 2001). These levels can be conceptualised as a value on a continuum. The levels (degrees) of identification with different foci may result in a conflict of interests, for example stronger career identification than organisational identification (Van Dick, 2001).

\section{Identity formation}

There are three distinct processes in the identity phenomenon, namely identity formation (e.g. identification), identity activation and resulting behaviours (Kirpal, 2004b). An identity develops through the interaction (a complex cognitive identity formation process) between an individual with a distinctive self, self-concept and personal identity and specific social foci (such as the social and/or work-related environment). Through the identity formation process, certain meanings, norms, expectations, beliefs and core values are derived from specific social foci (such as careers, professions, organisations, supervisors, work groups and job characteristics), which are cognitively and hierarchically 'stored' in prototypes (according to the social identity theory) or identity standards (according to the identity theory) (Abrams \& Hogg, 2004, Burke \& Stets, 2009; Hogg, 2001; Stryker \& Burke, 2000) and which are then ready to serve as behaviour guides (Kirpal, 2004b).

Depending on the work-related social foci, the work-related identity constructed may be referred to as professional, occupational, vocational or work identity (Crawford, Brown \& Majomi, 2008; Fugate, Kinicki \& Ashforth, 2004; Kirpal, 2004a, 2004b; Pratt et al., 2006). In response to perceptions received about a specific social situation, the most appropriate identity (behaviour guide) is selected and activated to guide behaviour (Buche, 2003, 2006, 2008; Hitlin, 2003; Hogg \& Ridgeway, 2003; Hogg \& Terry, 2000; Kirpal, 2004a, 2004b;
Olkkonen \& Lipponen, 2006; Stets \& Burke, 2003; Stryker \& Burke, 2000; Stryker \& Serpe, 1982; Tajfel, 1981; Tajfel \& Turner, 1985; Walsh \& Gordon, 2007). For a detailed review of the identity phenomena see Bothma (2011).

The above-mentioned body of research about identification provides the theoretical basis for exploring work-based identity as a potential construct in employee engagement research.

\section{Work-based identity}

For the purpose of this study, work-related identities are grouped together to form a multidimensional work-related identity referred to as a work-based identity. Work identity is conceptualised as a multilayered and multidimensional phenomenon that describes one's self-concept and one's understanding of it in terms of one's work role (Agostino, 2004; Baugher, 2003; Kirpal, 2004a; Tajfel \& Turner, 1985). Walsh and Gordon (2007) defined individual work identity as:

a work-based self-concept constituted of a combination of organisational, occupational and other identities that shape the roles individuals adopt and the corresponding ways they behave when performing their work in the context of their jobs and/or careers. (p. 2)

For the purpose of this study, work-based identity is defined as a multi-identity, multifaceted and multilayered construction of the self (in which the self-concept fulfils a core, integrative function), that shapes the roles of individuals who are involved in an employment context (Lloyd, Roodt \& Odendaal, 2011).

These meanings, norms, expectations, beliefs, and core values associated with a work-related identity are stored in a workbased identity prototype (adopted from the social identity theory). The work-based identity prototype can be divided into three different dimensions, namely a structural, social and individual-psychological dimension (Kirpal, 2004b). See Bothma (2011) and De Braine and Roodt (2011) for this conceptualisation and a detailed discussion of the workbased identity prototype.

Work-based identity (part of individual self-concept) has a significant influence on employee behaviour (Amiot, De la Sablonnière, Terry \& Smith, 2007), which in turn has an impact on work outcomes. This implies that the work-based identity of the collective labour force has an indirect but nevertheless significant impact on organisational performance (Agostino, 2004; Aryee \& Luk, 1996; Ashforth \& Kreiner, 1999; Wayne, Randel \& Stevens, 2006).

\section{Work engagement}

Around 1997, the positive organisational behaviour movement triggered a focus on the positive antithesis of burnout, namely work engagement (Maslach, 2003; Maslach \& Leiter, 1997). The construct work engagement from the perspective of the work environment quickly evolved in the practitioner community; academic research 
followed slowly. This bottom-up evolvement of engagement resulted in inconsistent interpretations of the meaning of the construct. For this reason, it is necessary to describe the conceptualisation of engagement as it came to be used in scholarly studies (Macey \& Schneider, 2008). In a review Simpson (2009) identified four lines of engagement research, namely personal engagement (Kahn, 1990), employee engagement (Harter et al., 2002), burnout and/or engagement (Leiter \& Maslach, 2004) and work engagement (Schaufeli \& Bakker, 2004).

For this study, the work engagement conceptualisation of Schaufeli and Bakker (2001), as measured by the Utrecht Work Engagement Scale (UWES) (Schaufeli \& Bakker, 2003), was used. Schaufeli et al. (2002) define work engagement as:

... a positive, fulfilling, work-related state of mind that is characterised by vigour, dedication and absorption. Rather than a momentary and specific state, engagement refers to a more persistent and pervasive affective-cognitive state that is not focused on any particular object, event, individual or behavior. (p. 74)

Vigour is '...characterised by high levels of energy and mental resilience while working, the willingness to invest effort in one's work and persistence even in the face of difficulties' (Schaufeli et al., 2002, p. 74).

Dedication is '... characterised by a sense of significance, enthusiasm, inspiration, pride and challenge' (Schaufeli et al., 2002, p. 74).

Absorption is '... characterised by being fully concentrated and deeply engrossed in one's work, whereby time passes quickly and one has difficulties with detaching oneself from work' (Schaufeli et al., 2002, p. 74).

Using theoretical analysis, Schaufeli and Bakker (2001) identified two underlying dimensions, activation and identification, for employee work-related wellbeing, as reflected in Figure 1.

Activation is conceptualised as a continuum with the antipodes exhaustion versus vigour (high levels of energy

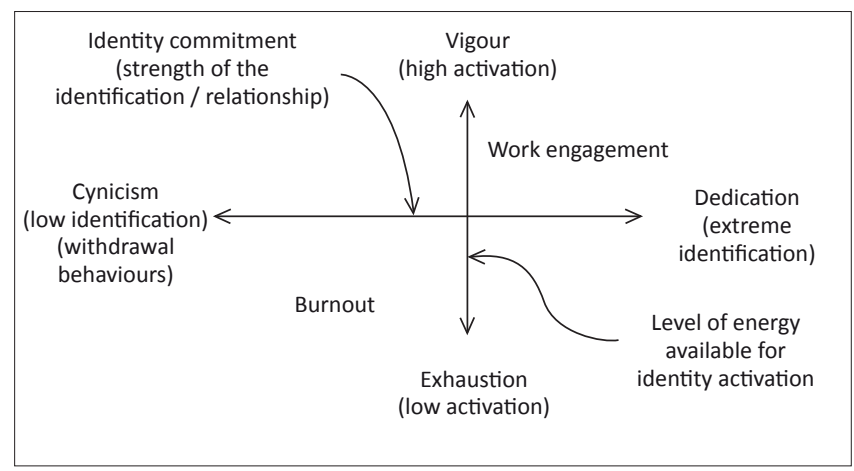

Source: Adapted from Schaufeli, W.B., \& Bakker, A.B. (2001). Werk en welbevinden: Naa een positiewe benadering in de arbeids- en gezondheidspsychologie. Gedrag en Organisatie, 229-253.

FIGURE 1: The Relationship between employees' identification with work and work-based identity activation. and mental resilience), whilst identification (cognitive state) is conceptualised as a continuum with the antipodes cynicism versus dedication. Cynicism (associated with low identification) reflects indifference or a distant attitude towards work in general, but not necessarily towards other people. Dedication (associated with high identification) refers to a strong involvement in one's work, with feelings of enthusiasm, significance, pride, and inspiration (Maslach, Jackson \& Leiter, 1996; Schaufeli et al., 2002). From this approach, burnout is associated with low activation and identification, whilst work engagement is associated with high activation and identification (Schaufeli et al., 2002). If the above-mentioned research is taken into account, it therefore appears that the sub-constructs vigour or work engagement and emotional exhaustion or burnout can play an active role during the activation phase of the identity process.

\section{Burnout}

The difficulties that arise when the relationship between an individual and his or her work goes awry are recognised as a serious phenomenon in the work environment (Maslach, Schaufeli \& Leiter, 2001). The psychological syndrome and multidimensional phenomenon described as burnout involves a prolonged response to stressors in the workplace (Maslach, 2003; Maslach et al., 1996). Burnout was initially conceptualised by Maslach and Jackson (1981) as a psychological syndrome that can occur in individuals who deliver some service to other people. In the available literature numerous theories have been formulated in an effort to explain the burnout phenomenon (Summers, 2010).

For this study, the burnout conceptualisation of Maslach and Jackson (1981), as measured by the Maslach Burnout Inventory - Human Services Scale (MBI-HSS) (Maslach et al., 1986; 1996) was used. This instrument was designed to measure burnout in people working in the human services and heath care environment. The three dimensions of burnout are emotional exhaustion, depersonalisation, and reduced personal accomplishment (Maslach, 2003; Maslach \& Jackson, 1981; Maslach et al., 1986, 1996; Maslach et al., 2001).

Emotional exhaustion is about '... feelings of being emotionally overextended and exhausted by one's work.' Depersonalisation is the '... unfeeling and impersonal response towards recipients of one's care or service.' Reduced personal accomplishment '... describes feelings of competence and successful achievement in one's work with people' (Maslach \& Jackson, 1981, p. 101). Garma, Bove and Bratton (2007) see the manifestation of burnout in three stages:

- emotional exhaustion (e.g., loss of energy)

- depersonalisation (e.g., an uncaring attitude towards customers and co-workers)

- reduced personal accomplishment (e.g., low motivation and reduced self-esteem).

Two schools of thought explain the relationship between burnout and work engagement. The first argues that burnout 
(negative) and work engagement (positive) are opposite poles on a continuum called work-related well-being. This theory is reflected in Figure 1 (Maslach, 2003; Maslach \& Leiter, 1997; González-Romá, Schaufeli, Bakker \& Lloret, 2006). The degree of work-related wellbeing is measured with the different versions of the Maslach Burnout Inventory (Maslach et al., 1986, 1996). Another group of researchers argue that, although work engagement is conceptualised as the direct opposite of burnout, it must be regarded as an independent state of mind that needs a different operational definition and measurement (Schaufeli \& Bakker, 2004).

\section{Personal alienation}

Using a motivational baseline, one school of thought conceptualised employee's identification with work as a position on a bipolar continuum. One end of this continuum represents alienation (under-identification), the centre represents commitment, and the other end represents extreme identification (Figure 1). Any form of withdrawal behaviour from work, also referred to by Bakker, Demeroutiand Verbeke (2004) as disengagement, such as absenteeism, will tend to manifest towards the alienation side on the continuum (Janse van Rensburg, 2004; Kanungo, 1979, 1982; Roodt, 1991, 1997). Under-identification with work manifests in withdrawal behaviours such as disengagement, absenteeism, turnover intention and low job performance (Bakker et al., 2004; Janse van Rensburg, 2004; Kanungo, 1979, 1982; Roodt, 1991, 1997).

Personal alienation is defined as '... a state of psychological separation from work in so far as work is perceived as lacking the potential to satisfy one's salient needs and expectations' (Kanungo, 1979, p. 131). Banai and Reisel (2007, p. 466) defined two manifestations of alienation in the work environment; firstly personal alienation that '... represents the phenomenological experience of profound disengagement covering a worker's sense of self' and secondly social alienation that is the '... connection to others'.

\section{Helping behaviour}

The work behaviour that employees display during a working period is referred to as job performance (Kahya, 2009). Motowidlo, Borman and Schmit, (1997, p. 71) defined job performance '... as the aggregated value to the organisation based on the discrete behavioural episodes that an individual performs over a standard interval of time'. Job performance is divided into task performance or in-role performance of '... activities that are formally recognised as part of their jobs' and a dimension referred to as contextual (also called citizenship) performance of activities ' ... not directly related to their main task function' (Kahya, 2009, p. 3; Motowidlo et al., 1997; Motowidlo \& Van Scotter, 1994).

A specific type of organisational citizenship behaviour (OCB) called helping behaviour, which is very similar to altruism and the facilitation dimension of contextual performance, is used in this study (LePine \& Van Dyne, 1998). Podsakoff, Mackenzie, Paine and Bachrach (2000, p. 516) defined helping behaviour as '... voluntary helping of others with or preventing the occurrence of work-related problems'.
For the purpose of this study, Van Dyne and LePine's (1998) definition was used. They hold that helping behaviour is:

... promotive behavior that emphasizes small acts of consideration. Helping is cooperative behavior that is noncontroversial. It is directly and obviously affiliative; it builds and preserves relationships; and it emphasizes interpersonal harmony. (p. 109)

The first part of the definition of helping behaviour includes various conceptualisations of helping behaviours, such as altruism, peace-making, cheerleading and interpersonal helping (Podsakoff et al., 2000).

\section{Task performance}

According to Motowidlo et al. (1997, p. 75) '... task performance bears a direct relation to the organization's technical core, either executing its technical processes or by maintaining and servicing its technical requirements'. For the purpose of this study the definition of Williams and Anderson (1991, p. 606) was used, which defines in-role (task) performance as ' ... behaviours that are recognized by formal reward systems and are part of the requirements as described in job descriptions'.

\section{Turnover intention}

As mentioned above, turnover intention is a type of withdrawal behaviour that is associated with underidentification with work (Bakker, et al., 2004; Janse Van Rensburg, 2004; Kanungo, 1979, 1982, Roodt, 1991, 1997, 2004b). Turnover intention is reflected in Figure 1. Turnover intention has been defined as the conscious and deliberate willingness to leave the organisation. It is regarded as the last in a sequence of withdrawal cognitions (Tett \& Meyer, 1993). Withdrawal behaviour is the primary way employees use to deal with issues in the employment relationship (Lo \& Aryee, 2003). Behavioural intention is a reliable determinant of actual behaviour. This implies that turnover intention can be used as a proxy for actual turnover (Jaros, Jermier, Koehler \& Sincich, 1993; Muliawan, Green \& Robb, 2009). Actual turnover behaviour is influenced by perceived alternative employment opportunities (Jaros et al., 1993; Senter \& Martin, 2007; Wheeler, Gallagher, Bouer \& Sablynski, 2007). The turnover phenomenon has significant cost consequences for any organisation. Losing highly skilled technical employees disrupts organisational functioning, service delivery and administration. It also contributes to hiring and training costs (Roodt \& Bothma, 1997; Sulu, Ceylan \& Kaynak, 2010). For the purpose of this study the definition of Tett and Meyer (1993, p. 262) is used, who defined turnover intention as '... the conscious and deliberate wilfulness to leave the organisation'.

\section{Relationship between work-based identity and work engagement}

From the available research literature it seems that workbased identity and work engagement share the subconstructs job involvement and commitment. The concept job involvement forms part of the individual-psychological dimension of the work-based identity prototype (Kirpal, 2004a, 2004b). 
The term job involvement is used to refer to the needsatisfying potential of a job (Rotenberry \& Moberg, 2007). It must be noted that job involvement is a construct distinct from work involvement which is a construct with a wider meaning (Hallberg \& Schaufeli, 2006; Paullay, Alliger \& Stone-Romero, 1994). Work engagement is defined by Schaufeli et al. (2002) as having the facets vigour, dedication, and absorption. The term dedication (in a qualitative sense) '... refers to a particularly strong involvement' (Schaufeli et al., 2002, p. 74). Job involvement in this sense refers to an aspect associated with the identification process, a '... cognitive or belief state' (Schaufeli et al., 2002, p. 74).

In their review of engagement, Macey and Schneider (2008) refer to the terms dedication and absorption, as defined by Salanova, Agut and Peiró (2005), as commitment and involvement respectively. As job involvement is a facet of work-based identity, and identity commitment is an indication of the strength of that identity, it was foreseen that there would be a strong positive correlation between workbased identity and work engagement.

Personal alienation, burnout and helping behaviour are closely related to work-based identity, work engagement, turnover intention and task performance. They were therefore included in the study so that a better understanding of their relationship with the key variables used in the study could be gained.

The following research hypothesis was based on the abovementioned discussion and formulated to investigate workbased identity and work engagement's prediction ability:

- Hypothesis 1: Work-based identity in combination with personal alienation, helping behaviour and burnout numerically explains more variance in turnover intention than work engagement does.

When a hierarchical regression model was used to predict turnover intention, a negative association between work identity (comprising of Aryee and Luk's [1996] 4-item identity scale) and turnover intention $(\beta=-0.34)$ was reported by Wayne et al. (2006). A strong negative relationship was reported between personal alienation and turnover intention (Sulu et al., 2010). Khalid and Ali (2005) reported a statistically significant negative relationship between facets of OCB (helping behaviour of organisational citizenship behaviour) and turnover intention. This finding implies that personal alienation and OCB are possible predictors of turnover intention. Schaufeli and Bakker (2004) presented evidence that engagement and turnover intention were related and that work engagement mediated the relationship between job resources and turnover intention. In the available research no evidence could be found that that work-based identity is a predictor of turnover intention:

- Hypothesis 2: Work-based identity in combination with personal alienation, helping behaviour and burnout numerically explains more variance in task performance than work engagement does.

Available research evidence indicates that work engagement is a predictor of job performance (Kahn, 1990, 1992; Harter et al., 2002; Leiter \& Maslach, 2004; Schaufeli et al., 2002). According to Bakker et al. (2004), research investigating the relationship between burnout and performance is scarce and conflicting results have been reported. According to the researchers the main reason for these conflicting results is possibly that several studies used only the exhaustion dimension of burnout together with self-reporting instruments and did not distinguish between contextual (extra-role) and task (in-role) performance. Wright and Bonett (1997) presented evidence that emotional exhaustion predicted work performance but they failed to establish a relationship between depersonalisation, reduced personal accomplishment and performance. Schaufeli and Bakker (2004) presented evidence that burnout was related to turnover intention and health problems. Cropanzano, Rupp and Byrne (2003) found that emotional exhaustion (the core facet of burnout) predicted performance and turnover intention. Cropanzano et al. (2003) reported a statistically significant positive relationship between $\mathrm{OCB}$ and job performance.

\section{Research design Research approach}

An empirical, quantitative research approach was followed, and a cross-sectional field survey was conducted that generated primary research data. Correlational data analysis techniques were applied in the study, and this provided plausible if ex post facto explanations for relationships.

\section{Research method Participants and sampling}

A census-based sampling approach ${ }^{1}$ was followed to survey the heterogenic population up to middle management $(N=23$ 134) in the employment of a large South African information and communication technologies (ICT) sector company over a period of one month. The survey was conducted with a web-based questionnaire application. A personal invitation was sent out by e-mail to the entire population, with the Universal Resource Locator (URL) address of the online survey attached. The response rate of $10.5 \%$ yielded a sample of 2429 research participants.

As can be seen in Table 1, most participants were male (63\%). The majority of the participants (44\%) were of White ethnicity followed by Black (26\%), Mixed race $(16 \%)$ and Asian or Indian ethnicity $(13 \%)$. The mean age of the participants was 40 years, an indication of a mature labour force.

\section{Measuring instruments}

The data were collected with a questionnaire that was webbased and supported by a database to capture the data. The

1.Before the term census-based sampling can be understood, the terms census and random sample need to be explained. In a census the whole target population is surveyed and participation is compulsory. A random sample on the other hand is a randomly selected portion of the target population; they can choose whether to a randomly selected portion of the target population; they can choose whether to participate in the survey or not. A census-based sampling approach enumerates al members of the target population (similar to a census) with the choice to participate in the survey or not. Self-selection bias (which falls outside the control of the researcher) equally affects response rates of census-based as well as other random sampling strategies. Because a census-based sampling approach enumerates the complete population as a sample, it is a more accurate sampling strategy compared to normal random sampling strategies where only small portions of the population are sampled. 
TABLE 1: Biographical and demographical profile of the respondents $(n=2429)$

\begin{tabular}{|c|c|c|c|}
\hline Variable & Category & $f$ & $\%$ \\
\hline \multirow[t]{4}{*}{ Age } & $20-29$ & 292 & 12.0 \\
\hline & $30-39$ & 960 & 39.5 \\
\hline & $40-49$ & 877 & 36.1 \\
\hline & $50+$ & 300 & 12.4 \\
\hline \multirow[t]{2}{*}{ Gender } & Female & 893 & 36.8 \\
\hline & Male & 1536 & 63.2 \\
\hline \multirow[t]{4}{*}{ Race } & Black & 640 & 26.3 \\
\hline & White & 1070 & 44.1 \\
\hline & Mixed race & 395 & 16.3 \\
\hline & Asian/Indian & 324 & 13.3 \\
\hline \multirow[t]{6}{*}{ Job Tenure } & $0-1$ & 205 & 8.4 \\
\hline & $2-5$ & 433 & 17.8 \\
\hline & $6-10$ & 700 & 28.8 \\
\hline & $11-15$ & 303 & 12.5 \\
\hline & $16-20$ & 226 & 9.3 \\
\hline & $20+$ & 562 & 23.1 \\
\hline \multirow[t]{4}{*}{ Education } & Grade 12 or less & 988 & 40.7 \\
\hline & Post-school certificate/diploma & 479 & 19.7 \\
\hline & $\begin{array}{l}\text { National Diploma/National Higher } \\
\text { Diploma }\end{array}$ & 653 & 26.9 \\
\hline & $\begin{array}{l}\text { Bachelor's degree or equivalent, or } \\
\text { more }\end{array}$ & 309 & 12.7 \\
\hline \multirow[t]{7}{*}{ Location } & Central & 119 & 4.9 \\
\hline & Corporate & 605 & 24.9 \\
\hline & Eastern & 318 & 13.1 \\
\hline & Gauteng & 450 & 18.5 \\
\hline & North Eastern & 336 & 13.8 \\
\hline & Southern & 159 & 6.5 \\
\hline & Western & 442 & 18.2 \\
\hline \multirow[t]{4}{*}{ Marital Status } & Single & 511 & 21.0 \\
\hline & Married or cohabiting & 1678 & 69.1 \\
\hline & Divorced or separated & 214 & 8.8 \\
\hline & Widowed & 26 & 1.1 \\
\hline \multirow[t]{3}{*}{ Level } & Management & 446 & 18.4 \\
\hline & Operational & 1334 & 54.9 \\
\hline & Specialist & 649 & 26.7 \\
\hline
\end{tabular}

$f$, frequency.

seven scales used for this study were the (1) Work-based Identity Scale (WI-28), (2) Burnout Scale (MBI-HSS-20), (3) Utrecht Work Engagement Scale (UWES-17), (4) Personal Alienation Scale, (5) Helping Behaviour Scale, (6) Turnover Intention Scale and (7) Task Performance Scale.

All the items of the survey, with the exception of the UWES and MBI-HSS-20 scales, were measured on a 7-point intensity response scale anchored at extreme poles ranging from 1 ('highly unlikely') or low intensity to 7 ('highly likely' or 'high intensity'). Participants were asked to use the measuring scale to indicate the degree to which the responses accurately described their own situation and feelings by clicking on the appropriate radio buttons.

Work-based Identity Scale: Although previous attempts had been made to measure work-based identity (Aryee \& Luk, 1996; Buche, 2003, 2006, 2008, Walsh \& Gordon, 2007; Wayne et al., 2006), no suitable measuring instrument was found that complied with the requirements of the theoretical definition of work-based identity. Therefore scales that measure individual facets of work-based identity as defined in the work-base identity prototype (Bothma, 2011), such as work role centrality, person-environment fit, organisational identification, job involvement, occupational and/or professional identity, and career identity, were sourced, adapted and combined to create a scale with which to measure work-based identity (Lauver \& Kristof-Brown, 2001; Lodahl \& Kejner, 1965; Mael \& Ashforth, 1992; Roodt, 1997; Roodt, De Braine, Bothma \& Jansen, 2009; Serafini, Maitland \& Adams, 2006).

A proposed Work-based Identity Scale was compiled, consisting of 36 items that represented the different facets of work-based identity. Items from the following scales were selected:

- Items were selected from the organisational-related commitment scale of Roodt (1997). Examples of the selected items are: 'To what extent do you regard work as the most important aspect in your life?' and 'To what extent does your job allow for the achievement of personal goals?'

- Job involvement was measured with items that were selected from Lodahl and Kejner's Job Involvement Scale (1965), for example 'How likely are you to regard your work as only a small part of who you are?'

- Items were also selected from three subscales of The Functions of Identity Scale of Serafini et al. (2006), namely structure (defined as '.. the structure of understanding of who one is'), goals (defined as '...meaning and direction through commitments, values and goals') and future (defined as '...meaning and direction through commitments, values and goals and sense of future').

- Organisational identification was measured with the scale of Mael and Ashforth (1992). Examples of the chosen items are: 'How often do you say "we" rather than "they" when you talk about the organisation that you work for?' and 'How interested are you in what others think about the organisation that you work for?'

- Person-organisation fit was measured with items from the scale of Lauver and Kristof-Brown (2001). Examples of the selected items are: 'To what degree do your values match or fit the values of the organisation that you work for?' and 'To what degree are you able to maintain your values at the organisation that you work for?'

- The reliability and validity of the instrument was determined by submitting the 36-item questionnaire to a first and second level factor analysis to determine factor structure. This yielded a 28-item, uni-dimensional Workbased Identity Scale with a Cronbach alpha of .95 (Roodt et al., 2009).

Utrecht Work Engagement Scale (UWES): The UWES was used to measure work engagement. The 17-item instrument is composed of three sub-constructs namely vigour (six items) with Cronbach alphas ranging from .75 to .82 , dedication (five items) with Cronbach alphas ranging from .88 to .90 , and absorption (six items) with Cronbach alphas ranging from .70 to .77 (Schaufeli et al., 2002). Examples of the selected items are: 'At my work, I feel bursting with energy' and 'Time flies when I'm working'. The work engagement items are scored on a 7-point Likert-type scale ranging from 0 ('never') to 6 
('always') where 0 and 6 represent extreme values on the scale (Schaufeli \& Bakker, 2003). This study found a Cronbach alpha of .91 for the UWES.

Maslach Burnout Inventory - Human Services Survey (MBIHSS-20): This scale was used to measure job burnout for this study. The 20-item instrument is composed of three subconstructs namely emotional exhaustion (eight items) with Cronbach alphas ranging from .85 to .90 , depersonalisation (i.e., negative, cynical attitudes and feelings about one's clients - five items), with Cronbach alphas ranging from .58 to .79 , and reduced personal accomplishment (seven items) with Cronbach alphas ranging from .70 to .71 (Gil-Monte, 2005; Maslach et al., 1996). Examples of the selected items are: 'I feel emotionally drained from my work' and 'I feel used up at the end of the work day.' The job burnout items are scored on a 7-point frequency rating scale ranging from 0 ('never') to 6 ('always') where the 6 and 0 represent extreme values on the scale (Maslach et al., 1986, 1996). This study found Cronbach alphas of .89 for emotional exhaustion, .70 for depersonalisation and .71 for reduced personal accomplishment.

Personal Alienation Scale: This scale was used to measure personal alienation (Banai, Reisel \& Probst, 2004; Korman, Wittig-Berman \& Lang, 1981). Examples of the 5-item Alienation Scale items are: 'To what extent do you feel that your daily activities don't reflect your real interests and values?' and 'How likely is it that you would prefer to live a different life than you are currently doing?' Banai and Reisel (2007) report a Cronbach alpha of .80 for personal alienation. This study found a Cronbach alpha of .81 for personal alienation.

Helping Behaviour Scale: was used to measure helping behaviour for this study. Examples of the 9-item Helping Behaviour Scale items that were selected are: 'How often do you volunteer to do things in your work group' and 'How often do you help others who have heavy workloads?' (Smith, Organ \& Near, 1983; Van Dyne \& LePine, 1998). Van Dyne and LePine (1998) reported a Cronbach alpha for the Helping Behaviour Scale in a range of .88 to .95 . This study found a Cronbach alpha of .86 for helping behaviour.

Turnover Intention Scale: Used to measure turnover intention (the intention to leave the job) (Roodt, 2004b). To enhance reliability, behaviour intention should be measured within a reasonable time frame. This study uses a six-month period, as recommended in the literature (Muliawan et al., 2009). A total of six items were adapted from this scale; examples are: 'How often have you considered leaving your job?' and 'How often do you look forward to another day at work?' Jacobs (2005) reported a Cronbach alpha of .91 for the Turnover Intention Scale. This study found a Cronbach alpha of .80 for turnover intention.

Task Performance Scale: This scale was used by supervisors to assess employees' task performance (Rotenberry \& Moberg, 2007; Williams \& Anderson, 1991). Examples of questions in the 9-item scale are: 'How often does this employee perform the tasks that are expected from them?' and 'How frequently does this employee fail to perform essential duties?' Care was taken not to include items related to contextual performance. Rotenberry and Moberg (2007) reported a Cronbach alpha of .91 for the Task Performance Scale. This study found a Cronbach alpha of .94 for task performance.

\section{Research procedure}

An electronic invitation to participate in the survey was sent to the ICT sector company employees up to middle management. The functionality of the web-based application was of such nature that it allowed for 'one-at-a-time completion' of the survey instruments. The successful completion of the questionnaire by the participant activated the last survey instrument, in-role job performance, to be completed by the participant's supervisor. Weekly electronic reminders were sent out to the target population reminding them to participate. Participation was voluntary and no incentives other than the reminders were used to enhance participation.

\section{Statistical analysis}

The SPSS Windows programme version 17 of SPSS International was used to conduct the statistical analysis (Pallant, 2007). The statistical techniques used were factor and reliability analysis, person correlations, stepwise multiple regression analysis and ANOVAS for mediation, and moderation testing.

\section{Results}

Distributions of item mean scores for Work-based Identity Scale, Work Engagement Scale, Turnover Intention Scale and Task Performance Scale are presented in Figure 1 to Figure 4.

As can be seen from Figure 1 and Figure 2, the distribution of item mean scores for the Work-based Identity Scale and the Utrecht Work Engagement Scale seems to be slightly negatively skewed. This trend is a desired outcome as one would want employees to have a high work-based identity and work engagement.

As can be seen from Figure 3 and Figure 4, distribution of item mean scores for the Turnover Intention Scale and Task Performance Scale seem to be negatively skewed. This trend is a desired outcome as employees are expected to be committed and display positive task performance behaviours towards the organisation.

The item inter-correlation matrix of all scales was tested for suitability for factor analysis by means of the Kaiser-MeyerOlkin (KMO) of Measure of Sampling Adequacy (MSA) and the Bartlett's Test of Sphericity (Kim, 2011; Pallant, 2005, 2007). The results of these tests are discussed below.

The results of the Kolmogorov-Smirnov and Shapiro-Wilk tests of the dataset indicated a violation of the assumption 


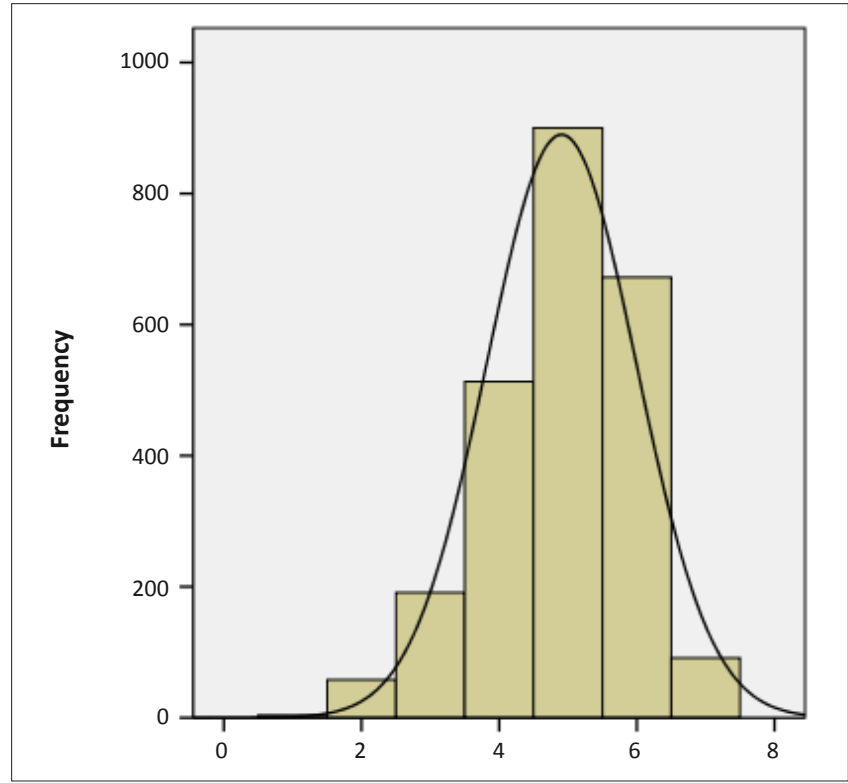

Source: Authors' own data

FIGURE 2: Frequency distribution of scores for the Work-based Identity Scale.

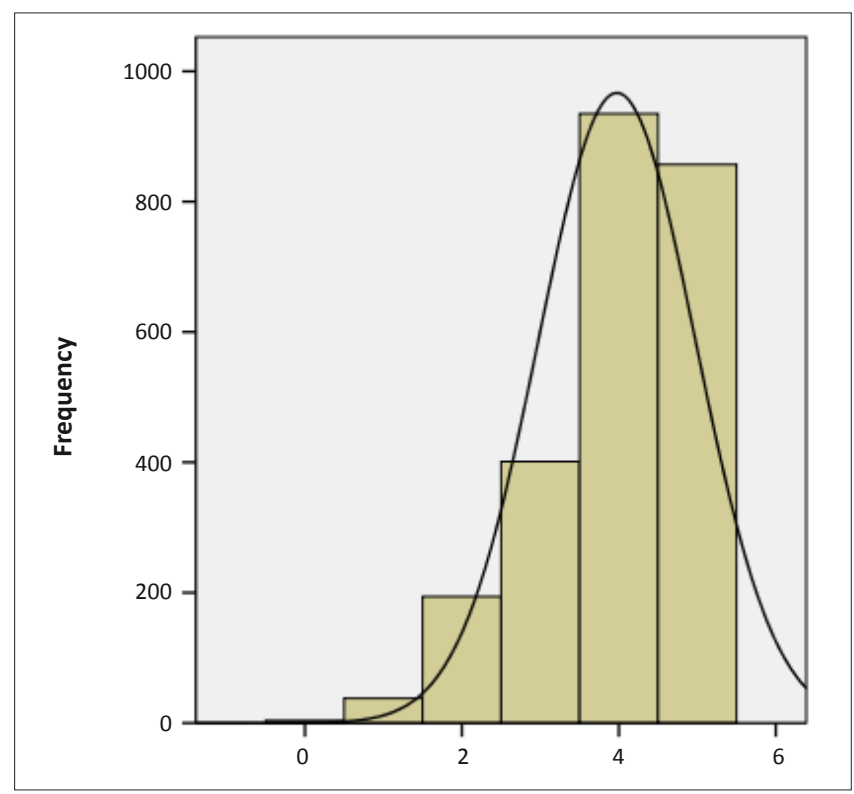

Source: Authors' own data

FIGURE 3: Frequency distribution of scores for the Utrecht Work Engagement Scale.

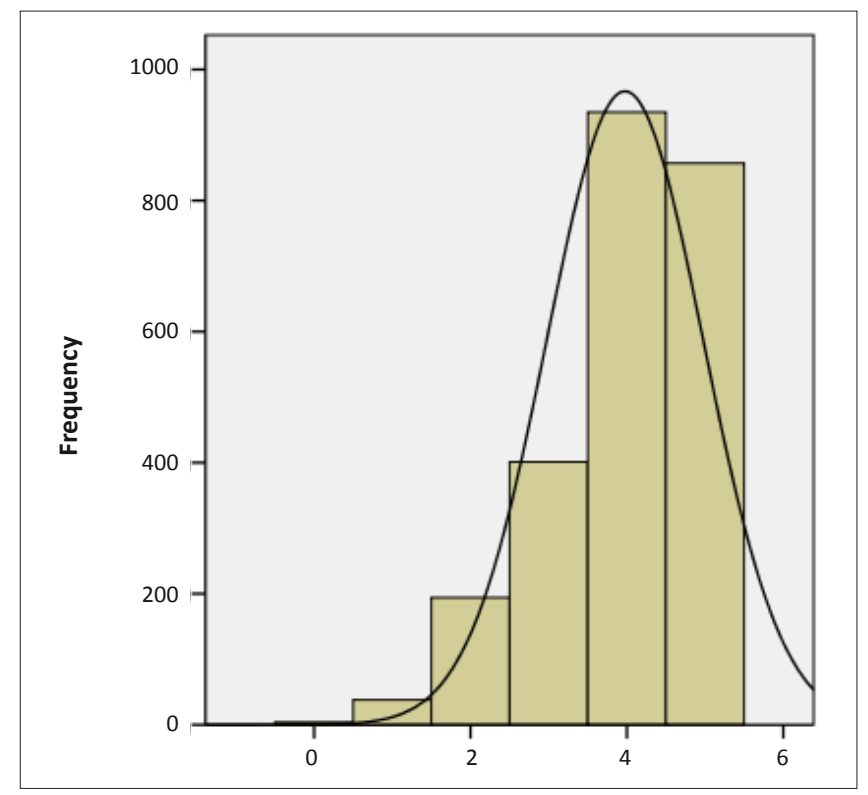

Source: Authors' own data

FIGURE 4: Frequency distribution of scores for the Turnover Intention Scale.

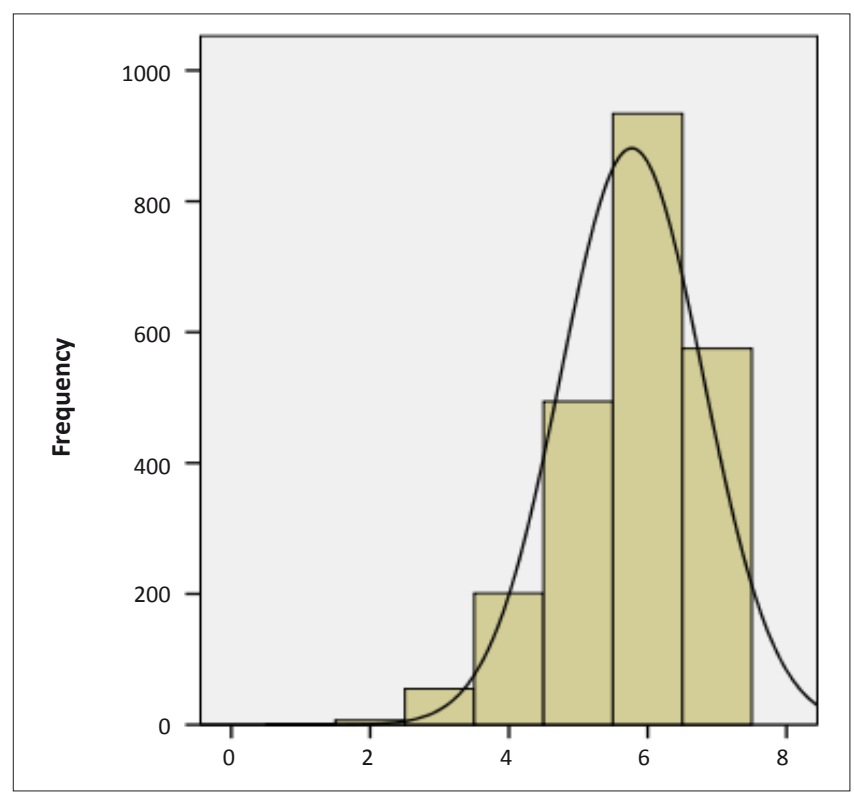

Source: Authors' own data

FIGURE 5: Frequency distribution of scores for the Task Performance Scale.

TABLE 2: Kolmogorov-Smirnov and Shapiro-Wilk tests for normality.

\begin{tabular}{|c|c|c|c|c|c|c|}
\hline \multirow[t]{2}{*}{ Constructs } & \multicolumn{3}{|c|}{ Kolmogorov-Smirnov ${ }^{a}$} & \multicolumn{3}{|c|}{ Shapiro-Wilk } \\
\hline & Statistic & $d f$ & Sig. & $d f$ & Sig. & $d f$ \\
\hline Work-based identity (WI) & 0.05 & 2.267 & 0.01 & 0.98 & 2.267 & $\leq .001$ \\
\hline Reduce personal accomplishment (PA) & 0.07 & 2.267 & 0.01 & 0.98 & 2.267 & $\leq .001$ \\
\hline Emotional exhaustion (EE) & 0.06 & 2.267 & 0.01 & 0.98 & 2.267 & $\leq .001$ \\
\hline Depersonalisation (DP) & 0.10 & 2.267 & 0.01 & 0.95 & 2.267 & $\leq .001$ \\
\hline Vigour (VI) & 0.16 & 2.267 & 0.01 & 0.89 & 2.267 & $\leq .001$ \\
\hline Dedication (DE) & 0.16 & 2.267 & 0.01 & 0.88 & 2.267 & $\leq .001$ \\
\hline Absorption (AB) & 0.14 & 2.267 & 0.01 & 0.90 & 2.267 & $\leq .001$ \\
\hline Personal alienation (AL) & 0.07 & 2.267 & 0.01 & 0.98 & 2.267 & $\leq .001$ \\
\hline Helping behaviour (H-OCB) & 0.07 & 2.267 & 0.01 & 0.96 & 2.267 & $\leq .001$ \\
\hline Turnover intention (TI) & 0.04 & 2.267 & 0.01 & 0.99 & 2.267 & $\leq .001$ \\
\hline Task performance (TP) & 0.11 & 2.267 & 0.01 & 0.93 & 2.267 & $\leq .001$ \\
\hline
\end{tabular}


of normality. As the significance values of both tests are respectively smaller than $p \leq .001$, it can be concluded that the dataset does not stem from a normal distribution. This violation of normality is not serious as long as the nonnormality is caused by data skewness and not by outliers in the data. The risk of drawing incorrect inferences is reduced if samples of greater than 200 are used (Tabachnick \& Fidell, 1996; 2001; 2007), considerably fewer than the sample of $n=2429$ used in this study. The data collected were therefore suitable for the parametric statistical procedures applied in the study. This statement is supported by Norman (2010, p. 631), who concluded that '... parametric statistics can be used with Likert data, with small sample sizes, with unequal variances, and with non-normal distributions, with no fear of "coming to the wrong conclusion".

\section{Factor and reliability analysis}

Item scores were intercorrelated and these matrices were tested by means of the Kaiser-Meyer-Olkin (KMO) of Measure of Sampling Adequacy (MSA) and the Bartlett's Test of Sphericity to determine their suitability for factor analysis. KMO-MSA values of all the scales exceed the recommended value of .6 (Hair, Anderson, Tatham \& Black, 1998).

A first level factor analysis was conducted on the item intercorrelation matrixes of the Work-based Identity Scale (WI-28), Personal Alienation Scale, Helping Behaviour Scale, Turnover Intention Scale, and Task Performance Scale as well as the three Burnout and UWES sub-scales to investigate their underlying factor structures. Principal Axis Factoring (PAF) was used as the extraction method, followed by a Varimax rotation with Kaiser Normalisation. Unidimensional factor structures were extracted for the Personal Alienation Scale, Helping Behaviour Scale, Turnover Intention Scale, Task Performance Scale, as well as the three Burnout and UWES sub-scales. All these scales or sub-scales yielded acceptable reliabilities (see Table 3).

Second-level factor analyses were conducted on the subscore intercorrelation matrixes on the three dimensions of the Maslach Burnout Inventory (MBI-HSS-20) and the three dimensions of the Utrecht Work Engagement Scale (UWES) to confirm their structure. For the Utrecht Work Engagement Scale (UWES) two factors that explained about $64 \%$ of the variance in the factor space were postulated by Kaiser's (1970) criterion and extracted by means of Principal Axis Factoring and a direct oblimin rotation. This finding does not confirm the three-factor structure of the UWES. The high correlations between the three dimensions vigour, dedication, and absorption reported by Storm and Rothmann (2003) are regarded as an indication that work engagement, as measured by the UWES, is possibly a one-dimensional construct. For the purpose of this study, work engagement was operationalised as a uni-dimensional scale. The threedimensional structure for the Maslach Burnout Inventory (MBI-HSS-20) was confirmed. The single-factor scale of work engagement and the burnout sub-scales yielded acceptable reliabilities.

\section{Second level factor analysis Work based Identity Scale (WI-28)}

Suitability of the $6 \times 6$ sub-score intercorrelation matrix for a second level factor analysis was confirmed with KMOMSA, which measured .78, that is above the recommended value of .6 (Hair et al., 1998). Bartlett's Test of Sphericity Chisquare value was statistically significant $\left(X^{2}(630)=3884.30\right.$; $p \leq .001)$, thereby indicating the appropriateness of the data for factor analysis. Two factors that explained about $66 \%$ of the variance in the factor space were postulated according to Kaiser's (1970) criterion and extracted by means of Principal Axis Factoring and a direct oblimin rotation. The results obtained from the iterative item reliability analysis of the Work-based Identity Scale, Factor 1, yielded a Cronbach Alpha of .95, indicating acceptable internal consistency reliability. The second extracted factor (that contained experimental items on 'future') did not form part of the theoretical conceptualisation of work-based identity and was omitted from further analysis. Work-based identity is therefore conceptualised as a uni-dimensional construct with acceptable internal consistency reliability.

Pearson correlations between the variables were calculated to determine the nature and strength of the bivariate relationships between the variables. The inter-correlation matrix for the study is presented in Table 3 below.

All the variables used in this study had a statistically significant relationship with work-based identity and work engagement. Note, for example, the differences in the correlations between work-based identity and work engagement with the other variables listed. A strong positive relationship was found to exist between work-based identity and work engagement $(r(2429)=0.71 ; p<.001)$.

It was anticipated that multicollinearity would not pose a problem in the predictive relationship between WE and WI. The Pearson product moment coefficients (see Table 3) showed a medium effect $(r(2429)=0.71 ; p<.001)$, and this is well below the level of concern $(r=.80)$ for collinearity to be present (Field, 2009; Hutcheson \& Sofroniou, 1999). Further regression analyses show that both the VIF and tolerance values of 1.0 for WI and WE are below five. The condition index (7.41) is below the stated threshold.

\section{Work-based identity predicting turnover intention}

Stepwise multiple regression analysis was used to produce a predictive model from the predictor variables work-based identity (WI), personal alienation (AL), helping behaviour (H-OCB), emotional exhaustion (EE), depersonalisation (DP), and reduced personal accomplishment (PA). The model is parsimonious and accurate because it excludes variables that do not contribute to explaining differences in the dependent variable turnover intention (TI) (see Table 4).

As reflected in Table 4, of all the predictor variables used in the stepwise multiple regression model, AL, EE, WI, H-OCB and PA contribute towards predicting TI. The five predictor variables accounted for $61 \%$ of the variance in TI. The regression coefficients of the predictor variables are ranked according to 
TABLE 3: Inter-correlation matrix (Pearson Correlations) of the different constructs.

\begin{tabular}{|c|c|c|c|c|c|c|c|c|c|c|c|}
\hline Constructs & $\mathbf{M}$ & SD & WI & $\mathrm{AL}$ & Н-ОСВ & PA & $\mathrm{EE}$ & DP & WE & $\mathrm{TI}$ & TP \\
\hline$\overline{W I}$ & 136.8 & 29 & {$[.95]$} & - & - & - & - & - & - & - & - \\
\hline $\mathrm{AL}$ & 20.76 & 7 & $-.56^{* *}$ & {$[.81]$} & - & - & - & - & - & - & - \\
\hline $\mathrm{H}-\mathrm{OCB}$ & 49.36 & 8.7 & $.37^{* *}$ & $-.13^{* *}$ & {$[.86]$} & - & - & - & - & - & - \\
\hline PA & 29.15 & 7.6 & $.35^{* *}$ & $-.22^{* *}$ & $.29^{* *}$ & {$[.71]$} & - & - & - & - & - \\
\hline $\mathrm{EE}$ & 19.82 & 12 & $-.39^{* *}$ & $.51^{* *}$ & $-.11^{* *}$ & $-.05^{*}$ & {$[.89]$} & - & - & - & - \\
\hline DP & 8.49 & 6.3 & $-.26^{* *}$ & $.33^{* *}$ & $-.07^{* *}$ & $-.05^{*}$ & $.66^{* *}$ & {$[.70]$} & - & - & - \\
\hline WE & 24.13 & 7 & $.71^{* *}$ & $-.62^{* *}$ & $.35^{* *}$ & $.42^{* *}$ & $-.40^{* *}$ & $-.27^{* *}$ & [.91] & - & - \\
\hline $\mathrm{TI}$ & 25.21 & 8.1 & $-.56^{* *}$ & $-.73^{* *}$ & $-.11^{* *}$ & $-.20^{* *}$ & $.56^{* *}$ & $.37^{* *}$ & $-.58^{* *}$ & {$[.80]$} & - \\
\hline TP & 51.75 & 8.8 & $.08^{* *}$ & $-.13^{* *}$ & $.11^{* *}$ & $.08^{* *}$ & $-.06^{* *}$ & $-.07^{* *}$ & $.09^{* *}$ & $-.13^{* *}$ & [.94] \\
\hline
\end{tabular}

M, mean; SD, standard deviation; WI, Work-based identity; AL, Personal alienation; H-OCB, Helping behaviour; PA, Reduce personal accomplishment; EE, Emotional exhaustion; DP, Depersonalisation; WE, Work engagement; TI, Turnover intention; TP, Task performance.

Coefficient alphas are presented in brackets along the diagonal.

$n=2429$

$*, p \leq .05 ; * *, p \leq .001$

TABLE 4: Results of stepwise multiple regression of work-based identity (WI), personal alienation (AL), helping behavior (H-OCB), deperonalisation (DP), reduce personal accomplishment (PA) and emotional exhaustion (EE) on turnover intention (TI).

\begin{tabular}{|c|c|c|c|c|c|c|c|c|c|}
\hline \multirow[t]{2}{*}{ Constructs } & \multicolumn{6}{|c|}{ Unstandardised coefficients } & \multicolumn{3}{|c|}{ Standardised coefficients } \\
\hline & $R$ & $R^{2}$ & Adjusted $R^{2}$ & $R^{2}$ Change & B & SE & $\beta$ & $t$ & $p$ \\
\hline (Constant) & - & - & - & - & 14.711 & 1.07 & - & 13.742 & .001 \\
\hline AL & $.731^{\mathrm{a}}$ & .534 & .534 & .534 & .572 & 0.019 & .493 & 29.81 & .001 \\
\hline EE & $.764^{\mathrm{b}}$ & .583 & .583 & .049 & .158 & 0.01 & .236 & 15.5 & .001 \\
\hline WI & $.782^{\mathrm{c}}$ & .611 & .611 & .028 & -.059 & 0.005 & -.213 & -12.857 & .001 \\
\hline $\mathrm{H}-\mathrm{OCB}$ & $.783^{d}$ & .613 & .613 & .002 & .068 & 0.016 & .058 & 4.214 & .001 \\
\hline PA & $.784^{\mathrm{e}}$ & .614 & .613 & .001 & .030 & 0.015 & .028 & 2.008 & .045 \\
\hline
\end{tabular}

$R$, multiple correlation; $R^{2}$, proportion variance explained; B, regression coefficient; SE, standard error; $\beta$, standardised regression coefficient; $t$, obtained $t$-test value; $p$, obtained significance value; AL, Personal alienation; EE, Emotional exhaustion; WI, Work-based identity; H-OCB, Helping behaviour; PA, Personal alienation.

Regression coefficients are significant at the $p \leq .001$ level.

Turnover intention (TI) is a dependant variable.

a, Predictors: (Constant), Personal alienation (AL)

, Predictors: (Constant), Personal alienation (AL); Emotional exhaustion (EE)

c, Predictors: (Constant), Personal alienation (AL); Emotional exhaustion (EE); Work-based identity (WI).

', Predictors: (Constant), Personal alienation (AL); Emotional exhaustion (EE); Work-based identity (WI); Helping behaviour (H-OCB).

e, Predictors: (Constant), Personal alienation (AL); Emotional exhaustion (EE); Work-based identity (WI); Helping behaviour (H-OCB); Reduce personal accomplishment (PA).

TABLE 5: Results of stepwise multiple regression of work engagement (WE), personal alientation (AL), helping behavior (H-OCB), depersonalisation (DP), reduce personal accomplishment (PA) and emotional exhaustion (EE) on turnover intention (TI).

\begin{tabular}{|c|c|c|c|c|c|c|c|c|c|}
\hline \multirow[t]{2}{*}{ Constructs } & \multicolumn{6}{|c|}{ Unstandardised Coefficients } & \multicolumn{3}{|c|}{ Standardised Coefficients } \\
\hline & $\boldsymbol{R}$ & $R^{2}$ & Adjusted $R^{2}$ & $R^{2}$ Change & B & SE & $\beta$ & $t$ & $p$ \\
\hline (Constant) & - & - & - & - & 14.19 & 0.931 & - & 15.241 & .001 \\
\hline AL & $.731^{\mathrm{a}}$ & 0.534 & 0.534 & 0.534 & 0.561 & 0.02 & 0.483 & 28.031 & .001 \\
\hline $\mathrm{EE}$ & $.764^{\mathrm{b}}$ & 0.583 & 0.583 & 0.049 & 0.159 & 0.01 & 0.237 & 15.648 & .001 \\
\hline WE & $.779^{c}$ & 0.607 & 0.607 & 0.024 & -0.083 & 0.007 & -0.214 & -12.64 & .001 \\
\hline $\mathrm{H}-\mathrm{OCB}$ & $.781^{\mathrm{d}}$ & 0.609 & 0.609 & 0.002 & 0.054 & 0.016 & 0.046 & 3.395 & .001 \\
\hline
\end{tabular}

$R$, multiple correlation; $R^{2}$, proportion variance explained; B, regression coefficient; SE, standard error; $\beta$, standardised regression coefficient; $t$, obtained $t$-test value; $p$, obtained significance value; AL, Personal alienation; EE, Emotional exhaustion; WE; Work engagement; $\mathrm{H}-\mathrm{OCB}$, Helping behaviour.

Regression coefficients are significant at the $p \leq .001$ level.

Turnover intention (TI) is a dependant variable.

a, Predictors: (Constant), Personal alienation (AL).

b, Predictors: (Constant), Personal alienation (AL); Emotional exhaustion (EE).

c, Predictors: (Constant), Personal alienation (AL); Emotional exhaustion (EE); Work engagement (WE)

', Predictors: (Constant), Personal alienation (AL); Emotional exhaustion (EE); Work engagement (WE); Helping behaviour (H-OCB).

their variance contribution, when the variance explained by the other variables in the model is accounted for. The beta coefficients reflect the regression weights of each predictor variable in the prediction of TI. The significance levels of all predictors in the model are less than $p \leq .001$.

The combined regression equation for turnover intention (TI) is as follows:

$\mathrm{TI}=14.711+0.572[\mathrm{AL}]+0.158[\mathrm{EE}]-0.059$

$[\mathrm{WI}]+0.068[\mathrm{H}-\mathrm{OCB}]+0.30[\mathrm{PA}]$

\section{Work engagement predicting turnover intention}

Stepwise multiple regression analysis was used to produce a predictive model from the selected predictor variables, $\mathrm{WE}$, $\mathrm{AL}, \mathrm{H}-\mathrm{OCB}, \mathrm{EE}, \mathrm{DP}$ and PA. The model is parsimonious and accurate because it excludes variables that do not contribute to explaining differences in the dependent variable turnover intention (TI) (see Table 5).

As reflected in Table 5, out of the predictor variables used in the stepwise multiple regression model, $\mathrm{AL}, \mathrm{EE}, \mathrm{WE}$ and H-OCB contribute towards predicting TI. The four predictor variables accounted for $61 \%$ of the variance in TI. The regression coefficients of the predictor variables are ranked according to their variance contribution, when the variance explained by the other variables in the model is accounted for. The beta coefficients reflect the regression weights of each predictor variable in the prediction of TI. The significance levels of all predictors in the model are less than $p \leq .001$. 
The combined regression equation for turnover intention (TI) can be formulated as:

$$
\begin{aligned}
& \mathrm{TI}=14.190+0.561[\mathrm{AL}]+0.159[\mathrm{EE}]-0.83[\mathrm{WE}]+ \\
& 0.54[\mathrm{H}-\mathrm{OCB}]
\end{aligned}
$$

\section{Work-based identity and work engagement predicting turnover intention}

Stepwise multiple regression analysis was used to produce a predictive model from the selected predictor variables, WI, $\mathrm{WE}, \mathrm{AL}, \mathrm{H}-\mathrm{OCB}, \mathrm{EE}, \mathrm{DP}$ and PA. The model is parsimonious and accurate because it excludes variables that do not contribute to explaining differences in the dependent variable turnover intention (TI) (see Table 6).

As reflected in Table 6, of the predictor variables used in the stepwise multiple regression model, AL, WE, EE and WI contribute towards predicting TI. The four predictor variables account for $62 \%$ of the variance in TI $\left(R^{2}=.620\right)$. It should be noted that $\mathrm{H}-\mathrm{OCB}$ has been omitted from the equation. The regression coefficients of the predictor variables are ranked according to their variance contribution, when the variance explained by the other variables in the model is accounted for. The beta coefficients reflect the regression weights of each predictor variable in the prediction of TI. The significance levels of all predictors in the model are less than $p \leq .001$.

The combined regression equation for turnover intention (TI) is as follows:

$\mathrm{TI}=19.409+0.544[\mathrm{AL}]-0.044[\mathrm{WE}]+0.153$

[EE] $-0.038[\mathrm{WI}]$

[Eqn 3]

\section{Work-based identity predicting task performance}

Stepwise multiple regression analysis was used to produce a predictive model from the selected predictor variables WI, $\mathrm{AL}, \mathrm{H}-\mathrm{OCB}, \mathrm{EE}, \mathrm{DP}$ and PA. The model is parsimonious and accurate because it excludes variables that do not contribute to explaining differences in the dependent variable task performance (TP) (see Table 7).

As reflected in Table 7, of all the predictor variables used in the stepwise multiple regression model, $\mathrm{AL}$ and $\mathrm{OCB}$ contribute towards predicting TP. The two predictor variables accounted for $3 \%$ of the variance in TI. The beta coefficients reflect the regression weights of each predictor variable in the prediction of TP. The significance levels of all predictors in the model are less than $p \leq .001$. The combined regression equation for task performance (TP) is as follows:

$\mathrm{TP}=48.082-0.144[\mathrm{AL}]+0.145[\mathrm{H}-\mathrm{OCB}]$

[Eqn 4]

\section{Work engagement predicting task performance}

Stepwise multiple regression analysis was used to produce a predictive model from the selected predictor variables WE, $\mathrm{AL}, \mathrm{H}-\mathrm{OCB}, \mathrm{EE}, \mathrm{DP}$ and PA. The model is parsimonious and accurate because it excludes variables that do not contribute to explaining differences in the dependent variable task performance (TP) (see Table 8 ).

As reflected in Table 8, of all the predictor variables used in the stepwise multiple regression model, $\mathrm{AL}$ and $\mathrm{OCB}$ contribute towards predicting TP. The two predictor variables accounted for $3 \%$ of the variance in TP. The beta coefficients reflect the regression weights of each predictor variable in the prediction of TP. The significance levels of all predictors in the model are less than $p \leq .001$. The combined regression equation for task performance (TP) is as follows:

$\mathrm{TP}=48.082-0.144[\mathrm{AL}]+0.145[\mathrm{H}-\mathrm{OCB}]$

[Eqn 5]

\section{Work-based identity and work engagement predicting task performance}

Stepwise multiple regression analysis was used to produce a predictive model from the selected predictor variables WI, WE, AL, H-OCB, EE, DP and PA. The model is parsimonious

TABLE 6: Results of stepwise multiple regression of work engagement (WE), work-based identity (WI), personal alienation (AL), helping behavior (H-OCB), depersonalisation

\begin{tabular}{|c|c|c|c|c|c|c|c|c|c|}
\hline \multirow[t]{2}{*}{ Constructs } & \multicolumn{5}{|c|}{ Unstandardised coefficients } & \multicolumn{4}{|c|}{ Standardised coefficients } \\
\hline & $\boldsymbol{R}$ & $R^{2}$ & Adjusted $R^{2}$ & $R^{2}$ Change & B & SE & $\beta$ & $t$ & $p$ \\
\hline (Constant) & - & - & - & - & 19.409 & .888 & - & 21.864 & .001 \\
\hline $\mathrm{AL}$ & $.731^{\mathrm{a}}$ & 0.534 & .534 & .534 & .544 & .020 & .469 & 27.279 & .001 \\
\hline $\mathrm{EE}$ & $.779^{c} \dagger$ & 0.607 & .607 & .040 & .153 & .010 & .227 & 15.081 & .001 \\
\hline WI & $.785^{d}$ & 0.617 & .616 & .009 & -.038 & .005 & -.138 & -7.585 & .001 \\
\hline
\end{tabular}
(DP), reduce personal accomplishment (PA) and emotional exhaustion (EE) on turnover indention (TI).

$R$, multiple correlation; $R^{2}$, proportion variance explained; B, regression coefficient; SE, standard error; $\beta$, standardised regression coefficient; $t$, obtained $t$-test value; $p$, obtained significance value; $\mathrm{AL}$, Personal alienation; WE, Work engagement; $\mathrm{EE}$, Emotional exhaustion; WI, Work-based identity.

Regression coefficients are significant at the $p \leq .001$ level.

Regression coefficients are significant at the $p \leq .001$
$\dagger$, Task performance (TP) is a dependent variable.

t, Task performance (TP) is a dependent variable.
a, Predictors: (Constant), Personal alienation (AL).

a, Predictors: (Constant), Personal alienation (AL)

, Predictors: (Constant), Personal alienation (AL); Work engagement (WE).

c, Predictors: (Constant), Personal alienation (AL); Work engagement (WE); Emotional exhaustion (EE).

d, Predictors: (Constant), Personal alienation (AL); Work engagement (WE); Emotional exhaustion (EE); Work-based intention (WI).

TABLE 7: Results of stepwise multiple regression of work-based identity (WI), personal alienation (AL), helping behavior (H-OCB), depersonalisation (DP), reduce personal

\begin{tabular}{|c|c|c|c|c|c|c|c|c|c|}
\hline \multirow[t]{2}{*}{ Constructs } & \multicolumn{6}{|c|}{ Unstandardised Coefficients } & \multicolumn{3}{|c|}{ Standardised Coefficients } \\
\hline & $\boldsymbol{R}$ & $R^{2}$ & Adjusted $R^{2}$ & $R^{2}$ Change & B & SE & $\beta$ & $t$ & $p$ \\
\hline (Constant) & - & - & - & - & 48.082 & 1.405 & - & 34.222 & .001 \\
\hline $\mathrm{AL}$ & $.130^{\mathrm{a}}$ & .017 & .016 & .017 & -.144 & .026 & -.115 & -5.519 & .001 \\
\hline
\end{tabular}
accomplishment (PA) and emotional exhaustion (EE) on task performance (TP).

$R$, multiple correlation; $R^{2}$, proportion variance explained; B, regression coefficient; $\mathrm{SE}$, standard error; $\beta$, standardised regression coefficient; $t$, obtained $t$-test value; $p$, obtained significance value; AL, Personal alienation; $\mathrm{H}-\mathrm{OCB}$, Helping behaviour.

Regression coefficients are significant at the $p \leq .001$ level.

Task performance (TP) is a dependent variable.

a, Predictors: (Constant), Personal alienation (AL).

', Predictors: (Constant), Personal alienation (AL); Helping behaviour (H-OCB). 
and accurate because it excludes variables that do not contribute to explaining differences in the dependent variable task performance (TP) (see Table 9).

The two predictor variables accounted for 3\% of the variance in TI. The beta coefficients reflect the regression weights of each predictor variable in the prediction of TP. It should be noted that both WI and WE are excluded in the prediction model. The significance levels of all predictors in the model are less than $p \leq .001$.

The combined regression equation for task performance (TP) is as follows:

$\mathrm{TP}=48.082-0.144[\mathrm{AL}]+0.145[\mathrm{H}-\mathrm{OCB}]$

[Eqn 6]

\section{Discussion}

The main purpose of the study was to determine whether there was a difference between work-based identity and work engagement (in combination with personal alienation, helping behaviour and burnout) as potential antecedents (amongst numerous others) of task performance and turnover intention. Although several researchers have made valuable contributions in WI research, their research seemed to be primarily focused on the antecedents and WI construction, transformation and maintenance processes, with little reference to the subjective and objective consequences (Agostino, 2004; Buche, 2003, 2006, 2008; Pratt et al., 2006; Walsh \& Gordon, 2007).

Similarly, WE-related research focused primarily on WE construction and maintenance, and inadequately on WE impact on organisational outcomes (Bakker \& Schaufeli, 2008; Macey \& Schneider, 2008; Schaufeli \& Bakker, 2001, 2003, 2004; Schaufeli et al., 2002; Schaufeli et al., 2006).

This study is, to our knowledge, one of the first to investigate the impact of both work-based identity and work engagement on selected organisational outcomes. The study further shows that it is worth making the distinction between workbased identity and work engagement.

\section{Summary of findings}

A strong, statistically significant positive relationship was found to exist between work-based identity and work engagement. This can possibly be attributed to the partial conceptual overlap between the two constructs as mentioned by Macey and Schneider (2008); Schaufeli et al. (2002); and Stets and Burke (2003); however, because this strong relationship does not pose a collinearity problem - as was confirmed by the collinearity statistics - it can be suggested that they are independent constructs in their own right.

There is a weak but statistically significant positive relationship between task performance, work-based identity and work engagement. There is a statistically significant high negative relationship between turnover intention (stay or leave), work-based identity and work engagement. A statistically significant high positive relationship was found between alienation and turnover intention (see Table 3). The statistically significant findings are in line with previous research that conceptualised alienation and turnover intention as withdrawal behaviour by individuals, that is a movement away from the social identity entities (Carmeli \& Gefen, 2005; Khalid \& Ali, 2005).

It was found that work-based identity in combination with the above-mentioned variables explains $61 \%$ of the variance in turnover intentions (see Table 4). AL emerged as the most important predictor of TI, and this is supported by previous research (Janse Van Rensburg, 2004; Roodt, 2004a). Another finding was that $\mathrm{H}-\mathrm{OCB}$ contributed positively towards predicting TI. This contradicts previous withdrawal research findings which indicated that if employees decided to leave the organisation, their contextual performance (OCBs) deteriorated (Lee \& Mitchell, 1994; Scroggins, 2008).

TABLE 8: Results of stepwise multiple regression of work engagement (WE), personal alienation (AL), helping behavior (H-OCB), depersonalisation (DP), reduce personal accomplishment (PA) and emotional exhaustion (EE) on task performance (TP).

\begin{tabular}{|c|c|c|c|c|c|c|c|c|c|}
\hline \multirow[t]{2}{*}{ Constructs } & \multicolumn{6}{|c|}{ Unstandardised Coefficients } & \multicolumn{3}{|c|}{ Standardised Coefficients } \\
\hline & $\boldsymbol{R}$ & $R^{2}$ & Adjusted $R^{2}$ & $R^{2}$ Change & B & SE & $\boldsymbol{\beta}$ & $t$ & $p$ \\
\hline (Constant) & - & - & - & - & 48.082 & 1.405 & - & 34.222 & .001 \\
\hline AL & $.130^{\mathrm{a}}$ & .017 & .016 & .017 & -.144 & .026 & -.115 & -5.519 & .001 \\
\hline $\mathrm{H}-\mathrm{OCB}$ & $.173^{\mathrm{b}}$ & .030 & .029 & .013 & .145 & .026 & .114 & 5.485 & .001 \\
\hline
\end{tabular}

$R$, multiple correlation; $R^{2}$, proportion variance explained; $\mathrm{B}$, regression coefficient; $\mathrm{SE}$, standard error; $\beta$, standardised regression coefficient; $t$, obtained $t$-test value; $p$, obtained significance value; AL, Personal alienation; H-OCB, Helping behaviour.

Regression coefficients are significant at the $p \leq .001$ level.

Regression coefficients are significant at the $p \leq$.
Task performance (TP) is a dependent variable.

Task performance (TP) is a dependent variable.

', Predictors: (Constant), Personal alienation (AL); Helping behaviour (H-OCB).

TABLE 9: Results of stepwise multiple regression of work-based identity (WI), work engagement (WE), personal alienation (AL), helping behavior (H-OCB), depersonalisation (DP), reduced personal accomplishment (PA) and emotional exhaustion (EE) on task performance (TP).

\begin{tabular}{|c|c|c|c|c|c|c|c|c|c|}
\hline \multirow[t]{2}{*}{ Constructs } & \multicolumn{6}{|c|}{ Unstandardised Coefficients } & \multicolumn{3}{|c|}{ Standardised Coefficients } \\
\hline & $R$ & $R^{2}$ & Adjusted $R^{2}$ & $R^{2}$ Change & B & SE & $\beta$ & $t$ & $p$ \\
\hline (Constant) & - & - & - & - & 48.082 & 1.405 & - & 34.222 & .001 \\
\hline AL & $.130^{\mathrm{a}}$ & .017 & .016 & .017 & -.144 & .026 & -.115 & -5.519 & .001 \\
\hline $\mathrm{H}-\mathrm{OCB}$ & $.173^{\mathrm{b}}$ & .030 & .029 & .013 & .145 & .026 & .114 & 5.485 & .001 \\
\hline
\end{tabular}

$R$, multiple correlation; $R^{2}$, proportion variance explained; $\mathrm{B}$, regression coefficient; $\mathrm{SE}$, standard error; $\beta$, standardised regression coefficient; $t$, obtained $t$-test value; $p$, obtained significance value;

AL, Personal alienation; H-OCB, Helping behaviour.
Regression coefficients are significant at the $p \leq .001$ level.

Regression coefficients are significant at the $p \leq 0$.

a, Predictors: (Constant), Personal alienation (AL).

$\stackrel{6}{\circ}$ Predictors: (Constant), Personal alienation (AL); Helping behaviour (H-OCB). 
It was found that WE in combination with the same variables also predicted $61 \%$ of the variance in TI (see Table 5). This result is in agreement with the findings of a meta-analysis by Harter et al. (2002). The stepwise multiple regression analysis did not support Hypothesis1 as it was found that there was no difference in the ability of WI or WE in combination with the other predictor variables to explain variance in TI (see Table 4 and Table 5). When both WE and WI were included in the regression equation, only a marginal improvement in variance $\left(\Delta R^{2}=0.009\right)$ occurred and $\mathrm{H}$-OCB was therefore excluded from the equation (see Table 6 ). It therefore seems as if the inclusion of WI with WE is a substitute for H-OCB. No other research could confirm this finding.

A statistically significant, but weak, positive relationship was found between work-based identity, work engagement and task performance (see Table 3). Stepwise multiple regression analysis was used to produce a predictive model that indicated that only AL and H-OCB emerged as important predictors of TP. No support for Hypothesis 2 was found (see Table 7, Table 8 and Table 9). This is not in accordance with the general perception that either WE or WI is a predictor of task performance (Bakker, Schaufeli, Leiter \& Taris, 2008; Harter et al., 2002; Macey \& Schneider, 2008; Simpson, 2009). These results may, however, also be attributable to the skewed task performance scores.

\section{Managerial implications and recommendations}

The most important production factor of any organisation is its human resources, as people act as the catalysts for unlocking other organisational resources. Employee behaviour impacts on subjectively (self-reporting) and objectively measured work outcomes, and these in turn impact on the bottom line of organisations (Walsh \& Gordon, 2007).

Work-based identity - the answer to the question 'Who am I at work?' - and work engagement play important roles in employee behaviour as they are indicators of employee energy to activate work-related identities. In the study it was found that both WI and WE had a strong statistically significant negative relationship with turnover intention (withdrawal behaviour) and both turned out to significant factors when variances in predicting turnover intention had to be explained. It is therefore suggested that organisations should always be on the lookout to find ways of improving employees' work experience, ways to engage the body, mind and soul of every employee (Bakker \& Schaufeli, 2008; Ulrich, 1997; Walsh \& Gordon, 2007). Organisations should include the reinforcement of social identification in the work environment (e.g., organisation, work group).

Social identification gives the individual a 'perception of oneness' (Ashforth \& Mael, 1989) with the organisation or work group, so that he or she is willing to take responsibility to ensure its success. The breakdown of work-based identities, for example through unfair personnel practices and retrenchments, have a significant impact on work outcomes (Agostino, 2004; Amiot et al., 2007).

\section{Limitations of the study}

The statistically significant positive correlation that was found between WI and WE $(r(2428)=0.7 ; p<.001)$ indicated that these constructs share about $50 \%$ variance and that there may be some evidence of concept redundancy. A similar finding was reported by De Braine and Roodt (2011) where selected job resources and demands were used to predict WI and WE. There may even be some degree of overlap with the burnout sub-scale personal accomplishment (PA), WI $(r(2428)=0.35 ; p<.001)$ and WE $(r(2428)=0.42 ; p<.001)$. The possible overlap in meaning between scales could have an impact on the research findings, and can be addressed by refining the measurements. Longitudinal research, specifically cross-lagged panel design studies, can also help to untangle the relationship between WI, WE, AL and the burnout dimensions EE, DP and PA.

The negative distribution of scores may have a serious truncation effect (restriction of range) when applied in a predictive model. No corrections were made for these truncation effects, which may be viewed as a limitation of the study.

\section{Suggestions for future research}

Future research can focus on the refinement of the workbased identity and the work engagement scales. This can be done by untangling the possible relationship that exists between work-based identity and work engagement, and taking the two work engagement dimensions identification and activation into consideration.

A work-based identity (or a set of work-related identities) is derived from work-related social foci through a process self-categorisation (social identity theory) or identification (identity theory) (Stets \& Burke, 2000). A score on the workbased identity measure can be expressed as a value on a bipolar identification continuum to reflect the degree of identification with specific foci. One pole of this identification continuum represents cynicism and/or alienation (underidentification) whilst the other pole represents dedication and/or workaholism (extreme identification) (adapted from Janse Van Rensburg, 2004; Kanungo, 1979; Roodt, 1991, 1997; Schaufeli \& Bakker, 2001).

The activation dimension can be conceptualised as a bipolar continuum with vigour (high levels of energy and mental resilience - a sub-construct of work engagement), as the positive pole, and exhaustion (low energy levels - a subconstruct of burnout) as the opposite pole (Maslach, 2003; Maslach \& Leiter, 1997; Schaufeli \& Bakker, 2001). Activation, as indicator of individuals' energy levels, may come into play once the work-based identity has been activated. An interesting study would be to investigate the reasons for the weak relationship between TP, WI and WE. From a practical perspective it would be interesting to investigate the impact of the management as key work-related foci on employee behaviour. 


\section{Conclusion}

The main objective of the study was to compare WI and WE, in combination with $\mathrm{AL}, \mathrm{H}-\mathrm{OCB}$, the burnout dimensions EE, PA and DP as possible predictors of TI (stay or leave) and TP. The findings reported here suggest that there is no numerical difference in the variances to be found between WI and WE in combination with the other predictors used in the study to predict turnover intention. The contribution of WI and WE to predict TP are statistically insignificant. The main objective of the study has therefore been achieved. Future research can focus on untangling the relationship between WI, WE and the burnout sub-scale PA and the refinement of WI measurement.

\section{Acknowledgements}

The research reported in this article is the product of a collaborative research project between the University of Johannesburg and the Vrije Universiteit Amsterdam. Financial support from the South Africa Netherlands Research Programme on Alternatives in Development (SANPAD) for conducting this research is hereby acknowledged. Conclusions drawn or opinions expressed in this article are those of the authors and do not necessarily reflect the views of SANPAD.

\section{Competing interests}

The authors declare that they have no financial or personal relationship(s) with the funding organisation which may have influenced them inappropriately when they wrote this article.

\section{Authors' contributions}

G.R. (University of Johannesburg) was the project leader of the larger Work Identity research project. F.C.B. (University of Johannesburg) conducted the research as part of his doctoral thesis and wrote most of the article's content. G.R. (University of Johannesburg) made further contributions in conceptualising, planning, executing and presenting the research article.

\section{References}

Abdelal, R., Herrera, Y.M., Johnston, A.I., \& Martin, T. (2001). Treating identity as a variable: Measuring the content, intensity, and contestation of identity. Retrieved, January 31, 2008, from http://www.people.fas/harvard.edu/ johnston/identity. pdf

Abrams, D., \& Hogg, M.A. (2004). Meta-theory: Lessons from social identity research Personality and Social Psychology Review, 8(2), 98-106. http://dx.doi.org/ $10.1207 / \mathrm{s} 15327957$ pspr0802 2

Agostino, J. (2004). Workplace identity. Unpublished doctoral thesis, Swinburne University of Technology, Hawthorn, Victoria, Australia.

Albert, S., Ashforth, B.E., \& Dutton, J.E. (2000). Organisational identity and identification: Charting new waters and building new bridges. The Academy of Management Review, 25(1), 13-17. http://dx.doi.org/10.5465/AMR.2000.2791 600

Amiot, C.E., De la Sablonnière, R., Terry, D.J., \& Smith, J.R. (2007). Integration of social identities in the self: Toward a cognitive-developmental model. Personality and Social Psychology Review, 11, 364-388. http://dx.doi.org/10.1177 /1088868307304091

Aryee, S., \& Luk, V. (1996). Work and non-work influences on the career satisfaction of dual-earner couples. Journal of Vocational Behavior, 49, 38-52. http://dx.doi. org/10.1006/jvbe.1996.0032
Ashforth, B.E., \& Humphrey, R.H. (1993). Emotional labor in service roles: The influence of identity. The Academy of Management Review, 18(1), 88-115.

Ashforth, B.E., \& Kreiner, G.E. (1999). 'How can you do it?' Dirty work and the challenge of constructing a positive identity. The Academy of Management Review, 24(3), 413-434.

Ashforth, B.E., \& Mael, F. (1989). Social identity theory and the organisation. The Academy of Management Review, 14(1), 20-39.

Bakker, A.B., Demerouti, E., \& Verbeke, W. (2004). Using the job demands-resources model to predict burnout and performance. Human Resource Management, 43(1), 83-104. http://dx.doi.org/10.1002/hrm.20004

Bakker, A.B., \& Schaufeli, W.B. (2008). Positive organisational behaviour: Engaged employees in flourishing organisations. Journal of Organisational Behavior, 29, 147-154.

Bakker, A.B., Schaufeli, W.B., Leiter, M.P., \& Taris, T.W. (2008). Work engagement: An emerging concept in occupational health psychology. Work \& Stress, 22(3), 187200. http://dx.doi.org/10.1080/02678370802393649

Banai, M., \& Reisel, W.D. (2007). The influence of supportive leadership and job characteristics on work alienation: A six-country investigation. Journal of World Business, 42, 463-476. http://dx.doi.org/10.1016/j.jwb.2007.06.007

Banai, M., Reisel, W.D., \& Probst, T.M. (2004). A managerial and personal control model: Predictions of work alienation and organisational commitment in Hungary. Journal of International Management, 10, 375-392. http://dx.doi.org/10.1016 /j.intman.2004.05.002

Baugher, J.E. (2003). Caught in the Middle? Worker identity under new participatory roles. Sociological Forum, 18(3), 417-439. http://dx.doi. org/10.1023/A:1025717619065

Bothma, F.C. (2011). The consequences of employees' work-based identity. Unpublished doctoral thesis, University of Johannesburg, South Africa.

Brewer, M.B. (2001). The many faces of social identity: Implications for political psychology. Political Psychology, 22(1), 115-125. http://dx.doi.org/10.1111/0162895X.00229

Brewer, M.B., \& Pierce, K.P. (2005). Social identity complexity and out-group tolerance. Personality and Social Psychology Bulletin, 31(3), 428-437. http://dx.doi.org /10.1177/0146167204271710

Buche, M.W. (2003). IT professional work Identity: Construct and outcomes. Unpublished doctoral thesis, University of Kansas, Lawrence.

Buche, M.W. (2006). Gender and IT professional work identity. In E. Trauth (Ed.), Gender and IT encyclopaedia, (pp. 434-439). University Park, PA: Information Science Publishing.

Buche, M.W. (2008). Influence of gender on IT professional work identity: Outcomes from a PLS study. Retrieved October 10, 2008, from http://portal.acm.org/ citation.cfm?id=1355272

Burke, P.J., \& Stets, J.E. (2009). Identity theory and social identity theory. Retrieved October 10, 2008, from http://www.scribd.com/doc/19720726/ identity-theoryand-social-identity-theory

Carmeli, A., \& Gefen, D. (2005). The relationship between work commitment models and employee withdrawal intentions. Journal of Managerial Psychology, 20(2), 63-85.

Coster, S., Norman, I., Murrells, T., Kitchen, S., Meerabeau, E., Sooboodoo, E., \& d'Avary, L. (2008). Interprofessional attitudes amongst undergraduate students in the health professions: A longitudinal questionnaire survey. International Journa of Nursing Studies, 45(11), 1667-1681.

Crawford, P., Brown, B., \& Majomi, P. (2008). Professional identity in community mental health nursing: A thematic analysis. International Journal of Nursing Studies, 45, 1055-1063.

Cropanzano, R., Rupp, D.E., \& Byrne, Z.S. (2003). The relationship of emotional exhaustion to work attitudes, job performance and organisational citizenship behaviors. Journal of Applied Psychology, 88(1), 160-169.

De Braine, R., \& Roodt, G. (2011). The job-demands-resources model as predictor of work identity and work engagement: A comparative analysis. SA Journal of Industrial Psychology, 37(2), Art. \#889, 11 pages. http://dx.doi:10.4012/sajip. v37i2.889

Field, A. (2009). Discovering statistics using SPSS. (3rd edn.). Thousand Oaks: Sage Publications.

Fugate, M., Kinicki, A.J., \& Ashforth, B.E. (2004). Employability: A psycho-social construct, its dimensions and applications. Journal of Vocational Behavior, 65(1), 14-38.

Garma, R., Bove, L.L., \& Bratton, V.K. (2007). Customer organisational citizenship behaviour: A coping mechanism in the stressor-strain-psychological job outcomes behaviour: A coping mechanism in the stressor-strain-psychological job outcomes
model. The Australian and New Zealand Marketing Academy (ANZMAC) Conference, (pp. 2557-2565). Dunedin, New Zealand: University of Otago.

Gil-Monte, P.R. (2005). Validacao factorial de Maslach Burnout Inventory (MBI-HSS) para profissionais espanhois. Rev Saude Publica, 39(1), 1-8.

González-Romá, V., Schaufeli, W.B., Bakker, A.B., \& Lloret, S. (2006). Burnout and work engagement: Independent factors or opposite poles? Journal of Vocational Behavior, 68, 165-174.

Hair, J.F., Anderson, R.E., Tatham, R.L., \& Black, W.C. (1998). Multivariate data analysis. (5th edn.). Upper Saddle River, N.J: Prentice-Hall International.

Hallberg, U., \& Schaufeli, W. B. (2006). 'Same same' but different? Can work engagement be discriminated from job involvement and organisational commitment? European Psychologist, 11, 119-127.

Harter, J.K., Schmidt, F.L., \& Hayes, T.L. (2002). Business-unit-level relationship between employee satisfaction, employee engagement, and business outcomes: a meta-analysis. Journal of Applied Psychology, 87(2), 268-279. 
Harter, J.K., Schmidt, F.L., \& Keyes, C.L.M. (2003). Well-being in the workplace and its relationship to business outcomes: A review of the Gallup studies. In C.L.M. Keyes \& J. Haidt (Eds.), Flourishing: Positive psychology and the life well-lived, (pp. Keyes \& J. Haidt (Eds.), Flourishing: Positive psychology and the
205-224). Washington: American Psychological Association.

Hitlin, S. (2003). Values as the core of personal identity: Drawing links between two theories of self. Social Psychology Quarterly, 66(2), 118-137.

Hogg, M.A. (2001). A social identity theory of leadership. Personality and Social Psychology Review, 5(3), 184-200. http://dx.doi.org/10.1207/S15327957PSP R0503_1

Hogg, M.A., \& Ridgeway, C.L. (2003). Social identity: Sociological and social psychological perspectives. Social Psychology Quarterly, 66(2), 97-100.

Hogg, M.A., \& Terry, D.J. (2000). Social identity and self-categorization processes in organisational contexts. Academy of Management Review, 25(1), 121-140.

Hogg, M.A., Terry, D.J., \& White, K.M. (1995). A tale of two theories: A critical comparison of identity theory with social identity theory. Social Psychology Quarterly, 58(4), 255-269.

Hutcheson, G.D., \& Sofroniou, N. (1999). The Multivariate Social Scientist: An introduction to generalized linear models. Thousand Oaks: Sage Publications.

Ibarra, H. (1999). Provisional selves: Experimenting with image and identity in professional adaptation. Administrative Science Quarterly, 44(4), 764-791.

Jacobs, E.J. (2005). The development of a predictive model of turnover intentions of professional nurses. Unpublished doctoral thesis, University of Johannesburg, South Africa.

Janse van Rensburg, K. (2004). A predictive model of employee commitment in an organisation striving to become world-class. Unpublished doctoral thesis, Rand Afrikaans University, Johannesburg, South Africa.

Jaros, S.J., Jermier, J., Koehler, J., \& Sincich, T. (1993). Effects of continuance, affective and moral commitment on the withdrawal process: an evaluation of eight structural equation models. Academic Management Journal, 36(5), 951-995.

Kahn, W.A. (1990). Psychological conditions of personal engagement and disengagement at work. Academy of Management Journal, 33, 692-724.

Kahn, W.A. (1992). To be fully there: Psychological presence at work. Human Relations, $45,321-349$.

Kahya, E. (2009). The effects of job performance on effectiveness. Internationa Journal of Industrial Ergonomics, 39(1), 96-104. http://dx.doi.org/10.1016/j. ergon.2008.06.006

Kaiser, H.F. (1970). A second generation little jiffy. Psychometrika, 35, 401-415.

Kanungo, R.N. (1979). The concepts of alienation and involvement revisited. Psychological Bulletin, 86(1), 119-138.

Kanungo, R.N. (1982). Measurement of job and work involvement. Journal of Applied Psychology, 67, 341-349.

Khalid, S.A., \& Ali, H. (2005). The effects of organisational citizenship behavior on withdrawal behavior: A Malaysian study. International Journal of Management and Entrepreneurship, 1(1), 30-40.

Kim, P.S. (2011). How to Choose a Factor Analysis Extraction Method in SPSS. Retrieved November 01, 2011, from http://www.ehow.com/how_7894964_choose-analysisextraction-method spss.html\#ixzz1/x4ugEOO

Kirpal, S. (2004a). Researching work identities in European context. Career Development International, 9(3), 199-221.

Kirpal, S. (2004b). Work identities of nurses. Between caring and efficiency demands Career Development International, 9(3), 274-304.

Korman, A.K., Wittig-Berman, U., \& Lang, D. (1981). Career success and personal failure: Alienation in professionals and managers. The Academy of Management Journal, 24, 342-361.

Korte, R.F. (2007). A review of social identity theory with implications for training and development. Journal of European Industrial Training, 31(3), 166-180.

Kreiner, G.E., Hollensbe, E.C., \& Sheep, M.L. (2006). Where is the ' $m e^{\prime}$ among the 'we'? Identity work and the search for optimal balance. Academy of Management Journal, 49(5), 1031-1057.

Lane, V.R., \& Scott, S.G. (2007). The neural network model of organisational identification. Organisational Behavior and Human Decision Processes, 104 175-192.

Lauver, K.J., \& Kristof-Brown, A. (2001). Distinguishing between employees perceptions of person-job and person-organisation fit. Journal of Vocational perceptions of person-
Behavior, 59, 454-470.

Lee, T.W., \& Mitchell, T.R. (1994). An alternative approach: The unfolding model of voluntary employee turnover. Management Review, 19(1), 51-89.

Leiter, M.P., \& Maslach, C. (2004). Areas of work life: A structured approach to organisational predictors of job burnout. In P.L. Perrewe \& D.C. Ganster (Eds.), Emotional and physiological processes and positive intervention strategies, research in occupational stress and well being, (vol. 3, pp. 91-134). Oxford: Elsevier.

LePine, J.A., \& Van Dyne, L. (1998). Predicting voice behavior in work groups. Journa of Applied Psychology, 83, 853-868.

LLoyd, S., Roodt, G., \& Odendaal, A. (2011). Critical elements in defining work-based identity in a post-apartheid South Africa. SA Journal of Industrial Psychology, 37(1), Art. \#894, 15 pages. http://dx.doi:10.4102/sajip.v37i1.894

Lo, S., \& Aryee, S. (2003). Psychological contract breach in a Chinese context: An integrative approach. Journal Management Studies, 40, 1005-1020.

Lodahl, T.M., \& Kejner, M. (1965). The definition and measurement of job involvement. Journal of Applied Psychology, 49, 24-33.
Macey, W.H., \& Schneider, B. (2008). The meaning of employee engagement. Industrial and Organisational Psychology, 1, 3-30.

Mael, F., \& Ashforth, B.E. (1992). Alumni and their alma mater: A partial test of the reformulated model of organisation. Journal of Organisational Behavior, 13, 103-123.

Maslach, C. (2003). Job burnout: New directions in research and intervention. Current Directions in Psychological Science, 12(5), 189-192.

Maslach, C., \& Jackson, S.E. (1981). The measurement of experienced burnout. Journal of Occupational Behavior, 2(2), 99-113.

Maslach, C., \& Leiter, M.P. (1997). The truth about burnout: How organisations cause personal stress and what to do about it. San Francisco: Jossey-Bass.

Maslach, C., Jackson, S.E., \& Leiter, M.P. (1986). Maslach Burnout Inventory Manual. (2nd edn.). Palo Alto, CA: Consulting Psychologists Press.

Maslach, C., Jackson, S.E. \& Leiter, M.P. (1996). Maslach Burnout Inventory Manual. (3rd edn.). Palo Alto, CA: Consulting Psychologists Press.

Maslach, C., Schaufeli, W.B., \& Leiter, M.P. (2001). Job Burnout. Annual review of Psychology, 52, 397-422.

Motowidlo, S.J., Borman, W.C., \& Schmit, M.J. (1997). A theory of individual differences and contextual performance. Human Performance, 10, 71-83.

Motowidlo, S.J., \& Van Scotter, J.R. (1994). Evidence that task performance should be distinguished from contextual performance. Journal of Applied Psychology, 79, 475-480.

Muliawan, A.D., Green, P.F., \& Robb, D.A. (2009). The turnover intentions of information systems auditors. International Journal of Accounting Information Systems, 10(3), 117-136.

Norman, G. (2010). Likert scales, levels of measurement and the 'laws' of statistics. Advances in Health Sciences Education, 15(5), 625-32. http://dx.doi.org 10.1007/ s10459-010-9222-y

Olkkonen, M.E., \& Lipponen, J. (2006). Relationships between organisational justice, identification with organisations and work-unit, and group-related outcomes. Organisational Behavior and Human Decision Processes, 100, 202-215.

Pallant, J. (2005). SPSS survival manual: A step by step guide to data analysis using SPSS version 15. (2nd edn.). New York: Open University Press.

Pallant, J. (2007). SPSS survival manual: A step-by-step guide to data analysis using SPSS version 15. (3rd edn.). New York: Open University Press.

Paullay, I.M., Alliger, G.M., \& Stone-Romero, E.F. (1994). Construct validation of two instruments designed to measure job involvement and work centrality. Journal of Applied Psychology, 79(2), 224-228.

Podsakoff, P.M., Mackenzie, S.B., Paine, J.B., \& Bachrach, D.G. (2000). Organisational citizenship behaviours: A critical review of the theoretical and empirical literature and suggestions for future research. Journal of Management, 26(3), 513-563.

Pratt, M.G., Rockmann, K.W., \& Kaufmann, J.B. (2006). Constructing professional identity: The role of work and identity learning cycles in the customization of identity among medical residents. The Academy of Management Journal, 49(2), 235-262.

Ravishankar, M.N., \& Pan, S.L. (2008). The influence of organisational identification on organisational knowledge management (KM). The International Journal of Management Science, Omega, 36(2), 221-234.

Reijn, L. (2007). Identity at work. Control and commitment in post bureaucratic organisations. Unpublished doctoral thesis, Vrije Universiteit, Amsterdam.

Roodt, G. (1991). Die graad van werkbetrokkenheid as voorspeller van persoonlike welsyn: 'n Studie by bestuurders [The degree of work involvement as predictor of personal well-being: A study amongst managers]. Unpublished doctoral thesis, University of the Orange Free State, Bloemfontein.

Roodt, G. (1997). Theoretical and empirical linkages between work-related commitment foci. SA Journal of Industrial Psychology, 23(2), 6-13.

Roodt, G. (2004a). Concept redundancy and contamination in employee commitment research: Current problems and future directions. SA Journal of Industrial Psychology, 30(1), 82-92.

Roodt, G. (2004b). Turnover Intentions. Unpublished manuscript, University of Johannesburg, Johannesburg, South Africa.

Roodt, G., \& Bothma, F.C. (1997). Die koste van vrywillige, beheerbare arbeidsomse [The cost of voluntary, controllable labour turnover]. SA Journal of Industria Psychology, 23(1), 26-30.

Roodt, G., De Braine, R., Bothma, F.C., \& Jansen, P. G. (2009). The Work-based Identity Questionnaire (WI-28). Unpublished questionnaire, University of Johannesburg, Johannesburg.

Rotenberry, P.F., \& Moberg, P.J. (2007). Assessing the impact of job involvement on performance. Management Research News, 30(3), 203-215.

Rousseau, D. (1998). Why workers still identify with organisations. Journal of Organisational Behavior, 19(3), 217-233.

Salanova, M., Agut, S., \& Peiró, J.M. (2005). Linking organisational resources and work engagement to employee performance and customer loyalty: The mediation of service climate. Journal of Applied Psychology, 90(6), 1217-1227.

Schaufeli, W.B., \& Bakker, A.B. (2001). Werk en welbevinden: Naar een positiewe benadering in de arbeids- en gezondheidspsychologie. Gedrag en Organisatie, 229-253.

Schaufeli, W.B., \& Bakker, A.B. (2003). UWES manual. Utrecht: Occupational Heath Psychology Unit, Utrecht University.

Schaufeli, W.B., \& Bakker, A.B. (2004). Job demands, job resources and their relationship with burnout and engagement: A multi-sample study. Journal of Organisational Behavior, 25, 293-315. 
Schaufeli, W.B., Bakker, A.B., \& Salanova, M. (2006). The measurement of work engagement with a short questionnaire. A cross-national study. Educational and engagement with a short questionnaire. A cross
Psychological Measurement, 66(4), 701-716.

Schaufeli, W.B., Salanova, M., Conźalez-Romá, V., \& Bakker, A.B. (2002). The measurement of engagement and burnout: A two sample confirmatory facto analytic approach. Journal of Happiness Studies, 3, 71-92.

Scroggins, W.A. (2008). The relationship between employee fit perceptions, job performance and retention: Implications of perceived fit. Employee Responsibilities and Rights Journal, 20, 57-71.

Senter, J.L., \& Martin, J.E. (2007). Factors affecting the turnover of different groups of part-time workers. Journal of Vocational Behavior, 71, 45-68.

Serafini, T.E., Maitland, S.B., \& Adams, G.R. (2006). The functions of identity scale Revisions, validation and model testing. Retrieved May 02, 2008, from www. w3.fiu.edu /srif/.../Serafini/

Simpson, M.R. (2009). Engagement at work: A review of the literature. International Journal of Nursing Studies, 46(7), 1012-1024.

Smith, C.A., Organ, D.W., \& Near, J.P. (1983). Organisational citizenship behavior: Its nature and antecedents. Journal of Applied Psychology, 68, 653-663.

Steers, R.M., \& Porter, L.W. (1991). Motivation and work behavior. (5th edn.). New York: McGraw-Hill.

Stets, J.E., \& Burke, P.J. (2000). Identity theory and social identity theory. Socia Psychology Quarterly, 63(3), 224-237.

Stets, J.E., \& Burke, P.J. (2003). A sociological approach to self and identity. In M Leary \& J. Tangney (Eds.), Handbook of self and identity, (pp. 128-152). New York: Guilford Press.

Storm, K, \& Rothmann, S. (2003). A psychometric analysis of the Utrecht Work Engagement Scale in the South African Police Service. SA Journal of Industrial Psychology, 29, 62-70.

Stryker, S., \& Burke, P.J. (2000). The past, present and future of an identity theory. Social Psychology Quarterly, 63(4), 284-297.

Stryker, S., \& Serpe, R.T. (1982). Commitment, identity salience, and role behavior. In W. Ickes \& E.S. Knowles (Eds.), Personality, Roles, and Social Behavior, (pp. 199218). New York: Springer-Verlag.

Sulu, S., Ceylan, A., \& Kaynak, R. (2010). Work alienation as a mediator of the relationship between organisational injustice and organisational commitment: implications for healthcare professionals. International Journal of Business and Management, 5(8), 27-38.
Summers, J. (2010). An analysis of the correlations between financial compensation burnout and demographic factors for mental health clinicians. Unpublished doctoral thesis, Capella University, Minneapolis.

Tabachnick, B.G., \& Fidell, L.S. (1996). Using multivariate statistics. (3rd edn.). New York: Harper Collins.

Tabachnick, B.G. \& Fidell, L.S. (2001). Using multivariate statistics. (4th edn.). Needham Heights: Allyn and Bacon.

Tabachnick, B.G., \& Fidell, L.S. (2007). Using multivariate statstics. (5th edn.). Boston: Pearson Education.

Tajfel, H. (1981). Human groups and social categories: Studies in social psychology. Cambridge: Cambridge University Press.

Tajel, H., \& Turner, J.C. (1985). The social identity theory of intergroup behavior. In S. Worchel \& W.G. Austin (Eds.), Psychology of Intergroup Relations, (2nd edn., pp. 7-24). Chicago: Nelson-Hall.

Tett, R.P., \& Meyer, J.P. (1993). Job satisfaction, organisational commitment, turnover intention and turnover: Path analysis based on meta-analytic findings. Personnel Psychology, 46(2), 259-293.

Ulrich, D. (1997). Human resource champions. Boston: Harvard Business School.

Van Dick, R. (2001). Identification in organisational contexts: Linking theory and research from social and organisational psychology. International Journal of Management Reviews, 3(4), 265-283.

Van Dyne, L., \& LePine, J.A. (1998). Helping and voice extra-role behaviors: Evidence of construct and predictive validity. Academy of Management Journal, 41(1), 108-120.

Walsh, K., \& Gordon, J.R. (2007). Creating an individual work identity. Human Resource Management Review, 18(1), 46-61.

Wayne, J.H., Randel, A.E., \& Stevens, J. (2006). The role of identity and work-family support in work-family enrichment and its work-related consequences. Journal of Vocational Behavior, 69, 445-461.

Wheeler, A.R., Gallagher, V.C., Brouer, R.L., \& Sablynski, C.J. (2007). When personorganisation (mis)fit and (dis)satisfaction lead to turnover. The moderating role of perceived job mobility. Journal of Management Psychology, 22(2), 203-219.

Williams, L.J., \& Anderson, S.E. (1991). Job satisfaction and organisational commitment as predictors of organisational citizenship and in-role behaviors. Journal of Management, 17(3), 601-617.

Wright, T.A., \& Bonett, D.G. (1997). The contribution of burnout to work performance. Journal of Organisational Behavior, 18(5), 491-499. 